\title{
Coordination Aspects in Modern Inorganic Chemistry
}

\author{
A.D. Garnovskii*,1, E.V. Sennikova ${ }^{1}$ and B.I. Kharisov*,2 \\ ${ }^{I}$ Institute of Physical and Organic Chemistry, Southern Federal University, Rostov-on-Don, Russia \\ ${ }^{2}$ CIIDIT-Universidad Autónoma de Nuevo León, Monterrey, Mexico
}

\begin{abstract}
Main types of coordination compounds in modern inorganic chemistry are discussed. Principal synthesis techniques for metal complexes and the problem of competitive coordination of ambident hard-soft ligands are discussed. A considerable attention is paid to polyfunctional materials, obtained on the basis of coordination compounds, especially molecular magnetics, organic light-emitting devices, and chemosensors.
\end{abstract}

Keywords: Coordination chemistry, competitive coordination, synthesis, biomimethics, metal complexes, functional materials.

\section{INTRODUCTION}

Generally, coordination chemistry is given as a part of inorganic chemistry courses (for example [1-5]) or as a special course on chemistry of complex compounds [6-11]. A multi-volume edition on general and coordination chemistry $[12,13]$, a series of monographs (for example [14]) and review articles [15-17], dedicated to the progress of modern chemistry of metal complexes, have been recently published. Results on this area have been published in more than 50 chemistry journals worldwide $[10,14]$. Among them, four journals are completely devoted to this area: "Journal of Coordination Chemistry", "Coordination Chemistry Reviews", "Polyhedron" and "Russian Journal of Coordination Chemistry". In three leading journals ("Inorganic Chemistry", "Inorganica Chimica Acta" and "Inorganic Chemistry Communications"), major part of articles corresponds to the field of coordination chemistry.

Coordination chemistry was founded by Swiss scientist A. Werner (1866-1919), who won Nobel Prize in 1913. Great contribution was further made by Russian chemist L.A. Chugaev (1873-1922). Coordination (complex) entities consist of a cationic, anionic, or neutral complex, containing a central atom or ion and molecules or ions, coordinated with it. Those substances, whose molecules contains a central atom, connected with ligands, can be considered as coordination or complex entities [6]. In all these compounds, the cations are surrounded with anions, neutral molecules or radicals. The groups, surrounding directly the cation, are named ligands; the area of inorganic chemistry, studying joint behavior of cations and their ligands, was named as coordination chemistry [10].

The discussions below include, in particular, bioinorganic compounds, mostly copper and vanadium complexes [5, 13(Vol. 8)].

*Address correspondence to these authors at the Institute of Physical and Organic Chemistry, Southern Federal University, Rostov-on-Don, Russia; E-mail: garn@ipoc.rsu.ru

CIIDIT-Universidad Autónoma de Nuevo León, Monterrey, Mexico; E-mail: bkhariss@ccr.dsi.uanl.mx

\section{CLASSIFICATIONS OF COORDINATION COM- POUNDS} $[6,17]$ :

Werner's classification according to ligand nature

1) Amino complexes $\mathrm{M}_{\mathrm{m}} \mathrm{A}_{\mathrm{n}}\left(\mathrm{NH}_{3}\right)_{\mathrm{p}}, \quad \mathrm{M}_{\mathrm{m}} \mathrm{A}_{\mathrm{n}}\left(\mathrm{NH}_{2} \mathrm{R}\right)_{\mathrm{p}}$, $\mathrm{M}_{\mathrm{m}} \mathrm{A}_{\mathrm{n}}\left(\mathrm{NHR}_{2}\right)_{\mathrm{p}}, \mathrm{M}_{\mathrm{m}} \mathrm{A}_{\mathrm{n}}\left(\mathrm{NR}_{3}\right)_{\mathrm{p}}$.

$\mathrm{R}=\mathrm{Alk}, \mathrm{Ar} ; \mathrm{m}=1,2 ; \mathrm{n}, \mathrm{p}=1-10 ; \mathrm{M}=\mathrm{d}$-metals; $\mathrm{A}$ $=\mathrm{Hal}^{-}, \mathrm{NO}_{2}^{-}, \mathrm{NO}_{3}^{-}, \mathrm{SO}_{4}{ }^{2-}$.

$\mathrm{CoCl}_{3} \cdot \mathrm{pNH}_{3}(\mathrm{p}=4-6), \mathrm{PtCl}_{4} \cdot \mathrm{pNH}_{3}(\mathrm{p}=2-6), \mathrm{M}_{\mathrm{m}} \mathrm{A}_{\mathrm{n}} \mathrm{L}_{\mathrm{p}}$, $\mathrm{L}=\mathrm{H}_{2} \mathrm{NCH}_{2} \mathrm{CH}_{2} \mathrm{NH}_{2}$ (En) - ethylenediamine, Py - pyridine, $\mathrm{p}=1-3$.

2) Aqua complexes - $\mathrm{M}_{\mathrm{m}} \mathrm{A}_{\mathrm{n}}\left(\mathrm{H}_{2} \mathrm{O}\right)_{\mathrm{p}}, \mathrm{CoCl}_{2} \cdot 6 \mathrm{H}_{2} \mathrm{O}$, $\mathrm{NiCl}_{2} \cdot 6 \mathrm{H}_{2} \mathrm{O}, \mathrm{CuCl}_{2} \cdot 4 \mathrm{H}_{2} \mathrm{O}, \mathrm{CuSO}_{4} \cdot 5 \mathrm{H}_{2} \mathrm{O}$.

3) Mixed-ligand complexes.

Aminoaqua complexes $\mathrm{PtCl}_{4} \cdot\left(\mathrm{NH}_{3}\right)_{6} \mathrm{H}_{2} \mathrm{O}, \mathrm{Co}\left(\mathrm{NO}_{2}\right)_{2}$ $\left(\mathrm{NH}_{3}\right)_{3} \cdot 2 \mathrm{H}_{2} \mathrm{O}$.

Ethylenediaminoaqua complexes $\mathrm{CoCl}_{3}(\mathrm{En})_{3} \cdot 3 \mathrm{H}_{2} \mathrm{O}$.

Aminoethylenediaminoaqua $\mathrm{PtCl}_{4}\left(\mathrm{NH}_{3}\right)_{4}(\mathrm{En}) 2 \mathrm{H}_{2} \mathrm{O}$.

Classification of G. Beilar and D. Bush according to the type of ligand donor centers $N, P, O, S$ [18]. This is the most common classification, which is widely used in monographs and systematization of a ligating compounds [14]. Not only classic donor centers are examined (C, N, P, As; O, S, Se, Te; B), but also their various combinations such as $\mathrm{C}, \mathrm{N} ; \mathrm{C}$, $\mathrm{O} ; \mathrm{C}, \mathrm{S} ; \mathrm{N}, \mathrm{P} ; \mathrm{N}, \mathrm{As} ; \mathrm{N}, \mathrm{O} ; \mathrm{N}, \mathrm{S} ; \mathrm{N}, \mathrm{Se} ; \mathrm{N}, \mathrm{Te} ; \mathrm{O}, \mathrm{S} ; \mathrm{O}, \mathrm{Se}$; $\mathrm{O}, \mathrm{Te} ; \mathrm{B}, \mathrm{N} ; \mathrm{B}, \mathrm{O} ; \mathrm{B}, \mathrm{S}$ [14].

Other approaches to complex classifications are reported in the monograph of K. Day and D. Selbin [3], but their use is limited:

1) According to coordination number $(\mathrm{CN}) 2 \div 10$; however, $~ 90 \%$ of known complexes have $\mathrm{CN}=4,5,6$.

2) According to oxidation number of a metal complexformer.

3) According to nature of a coordination bond: $\sigma, \pi, \delta$ or their combinations. 
4) According to electronic configuration of a complexformer.

Moreover, complexes can be classified according to number of metallic centers in the complexes and the dentacity of ligands [3].

An optimal classification is that which examines a complex molecule in whole: donor atoms, $\mathrm{CN}$, bond nature and metal complex-former oxidation number. According to this classification, metal complexes can be divided in five types [17]: molecular complexes, metallocyclic complexes (chelates), complexes with multi-central bonds, di- and polimetallic complexes and supramolecular coordination complexes. This classification [14, 17] comprehends all known types of metal complexes and concentrates attention on peculiarities of types of molecules in complexes and not of their separate parts $[3,16,18]$.

In a book of Nobel laureate J.M. Lehn "Supramolecular chemistry" [19], self-assembling of supramolecular complexes is related with coordinative interactions. It is noted that "chemistry of receptors" (recognizing cations, anions or neutral molecules) represents "generalized coordination chemistry".

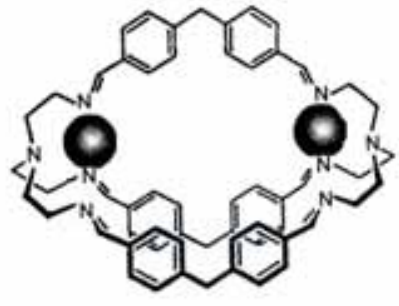

1

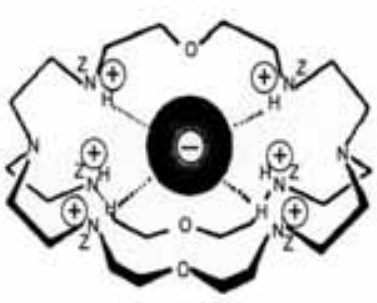

2

We note that some supramolecular structures may contain, as central atoms, not only cations $\mathbf{1}$, but also anions, for instance halides 2 (details in [7-10, 19-21]).

\section{Molecular Complexes $M_{m} A_{n} L_{p}{ }^{1} L_{q}{ }^{2}[6,14,17]$}

Werner's complexes (the basis of coordination chemistry in the end of XIX and beginning of XX century) belongs to this type of complexes $[6,17]$. When $p$ or $q=0$, the complexes contain the same ligands (homoleptic complexes); if $\mathrm{q} \neq 0$, they contain distinct ligands. Among these complexes, neutral (for instance $\left[\mathrm{BF}_{3} \mathrm{NH}_{3}\right]$ ), cationic $\left(\left[\mathrm{Al}\left(\mathrm{H}_{2} \mathrm{O}\right)_{6}\right]^{3+} \mathrm{Cl}_{3}\right)^{-}$ and anionic $\left(\mathrm{K}_{4}^{+}\left[\mathrm{Fe}(\mathrm{CN})_{6}\right]^{4-}\right)$ are known. The simplest ligand is a hydride anion, which belongs to dielectronic $\sigma$-donors [14] and forming a series of complexes, for example 3 and 4 .

\section{$\left[\mathrm{HCo}(\mathrm{CO})_{4}\right]$}

\section{3}

$\left[\mathrm{HPtBr}\left(\mathrm{PPh}_{3}\right)_{2}\right]$

Carbon ligand is a part of clusters $\mathbf{5}$ or $\pi$-complexes $\mathbf{6}$.

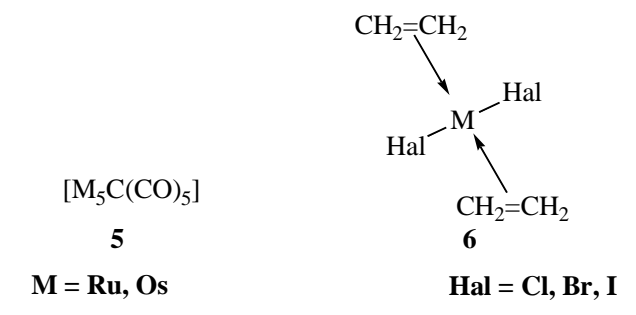

Mono- and dinuclear complexes with diatomic nitrogen, phosphorus, and arsenicum (E) molecules 7a-c, having various coordination modes, are well-known.

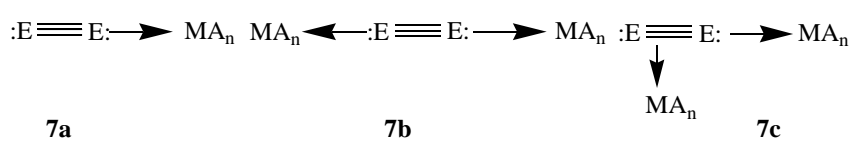

Among triatomic molecular ligands, we note carbon dioxide 8, according to the importance to resolve the problem of binding $\mathrm{CO}_{2}$ evolving to the atmosphere.

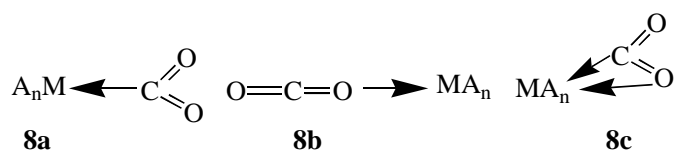

Dialkyl(aryl)sulfoxide complexes 9-11 have been also reported.

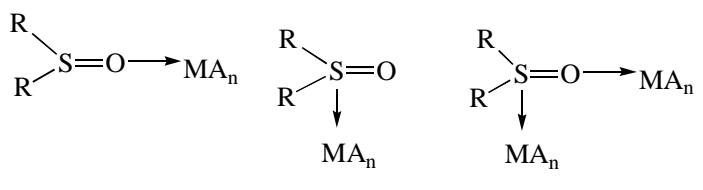

$$
\begin{aligned}
& 9 \begin{array}{lll}
9 & 10 & 11
\end{array}
\end{aligned}
$$

Molecular complexes of azoles 12, azines $\mathbf{1 3}$ and their derivatives 14-17 are of high interest at present [5, 13, 14, 22].

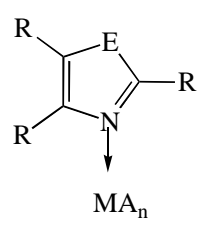

12<smiles>[Y19][n+]1ccccc1</smiles>

13<smiles></smiles>

14<smiles></smiles>

15<smiles></smiles>

16

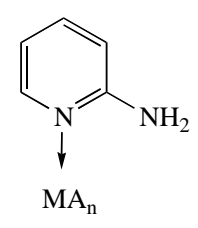

17

$$
\mathrm{E}=\mathrm{NR}, \mathrm{O}, \mathrm{S}, \mathrm{Se}, \mathrm{Te} ; \mathrm{R}=\mathrm{H}, \mathrm{Alk}, \mathrm{Ar}
$$

\section{Metallocyclic Complexes (Chelates) $[5,14,15]$}

In these complexes, metal cycles with distinct number of bonds were observed; among them, 5- or 6-member rings are the most stable, for example 18-22 [10, 15].

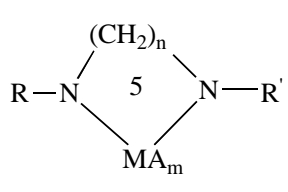

18<smiles>[R]N1CN([R])c2ccccc21</smiles>

19<smiles>[R]N([R])c1ccccc1C=[N+]([R])N([R])[R]</smiles>

20
R, R' = H, AIK, Ar;

$\mathbf{m}=\mathbf{1 - 5}$

n = 1-6;
$\mathbf{R}=\mathbf{H}, \mathbf{A I K}, \mathbf{A r}, \mathbf{T s}$

$\mathbf{T s}=-\mathrm{SO}_{2} \mathbf{R}^{\prime}$;

$\mathbf{R}^{\prime}=\mathrm{Me}, \mathrm{Ar} \mathbf{m}=\mathbf{2 , 3}$ 


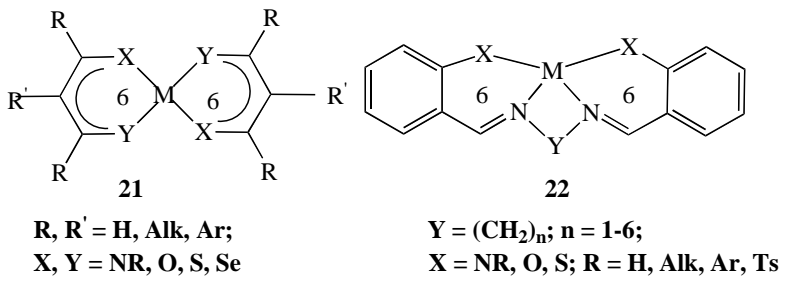

Azine 23, 24 and azole 25 complexes with 5- and 6-member cycles have been isolated.<smiles>[X]c1cccc2ccc[n+]([Y19])c12</smiles>

23
Formation of $\mathrm{C}, \mathrm{N}$-cyclometallated 5-member chelate structures 26, 27 was noted [14, 23].

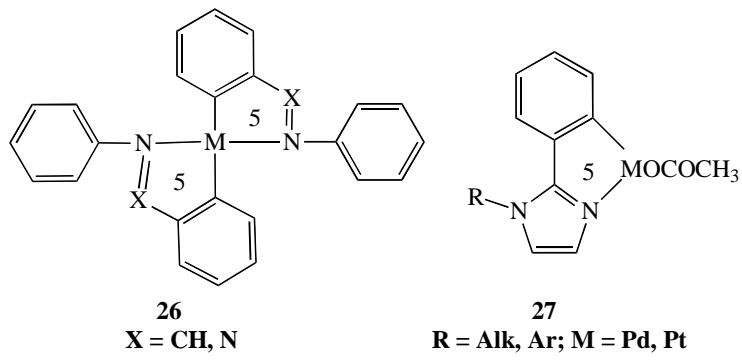

\section{Complexes with Multi-Centered Bonds (CMB) [14]}

This type of complexes is formed by compounds with delocalized bonds. Examples of less-common coordination compounds are complexes of four- (28), five- (29) and six(30) member boron-nitrogen systems [14].

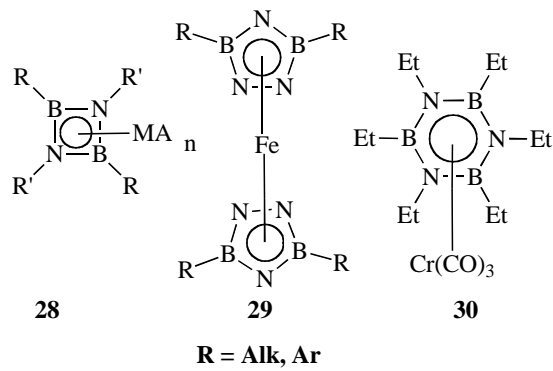

Cene complexes 31 (especially ferrocene 31, $\mathrm{M}=\mathrm{Fe}$ ) and dibenzene metal sandwich structures 32 (especially dibenzenechromium 32, $\mathrm{M}=\mathrm{Cr}$ ) are well-known $[5,14]$.

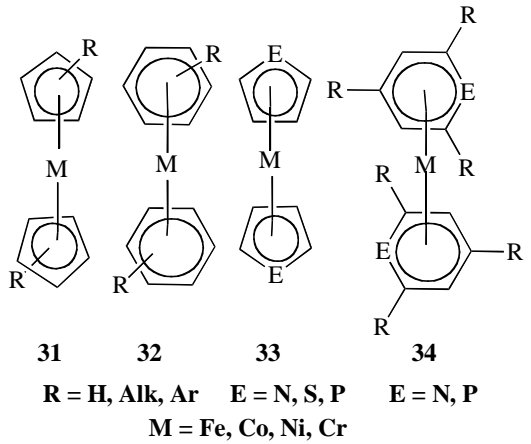

Heteroaromatic sandwich compounds of types $\mathbf{3 3}$ and $\mathbf{3 4}$ are also well-known [5, 22], as well as three-decker complexes of phosphorus- $(\mathbf{3 5})$ and boron- $(\mathbf{3 6}, \mathbf{3 7})$ containing heterocycles [14].

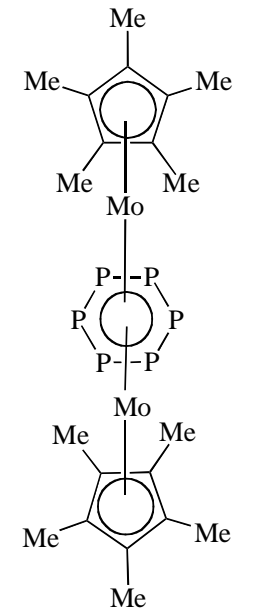

35

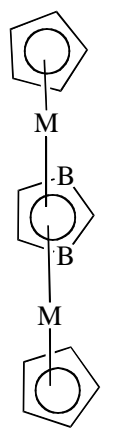

36

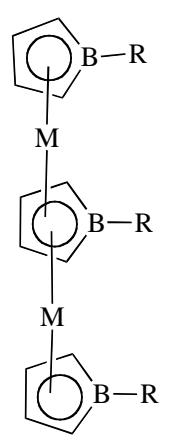

37

Numerous $\mathrm{CMB}$ are formed by instable organic species: radicals 38-41, biradicals 42 , carbenes 43 and carbines 44 [14].<smiles></smiles>

38

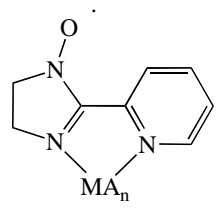

40

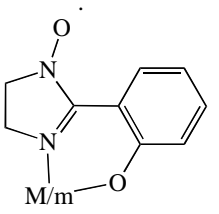

41

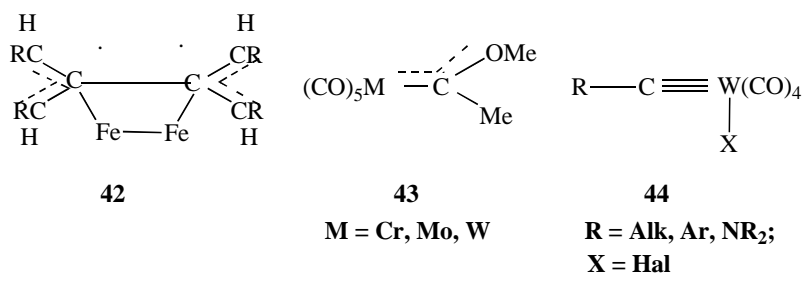

\section{Di- and Polimetallic Complexes [5, 14]}

Werner's structures are also known among complexes of this type, for instance complexes 45 and $\mathbf{4 6}$ [6, 14].

$\left[\left(\mathrm{H}_{3} \mathrm{~N}\right)_{2} \mathrm{Pt}(\mathrm{SCN})_{2} \mathrm{Ag}\right] \mathrm{NO}_{3}$

45

Di- and polinuclear complexes having multiple bonds are examined in detail, for example 47 [24].

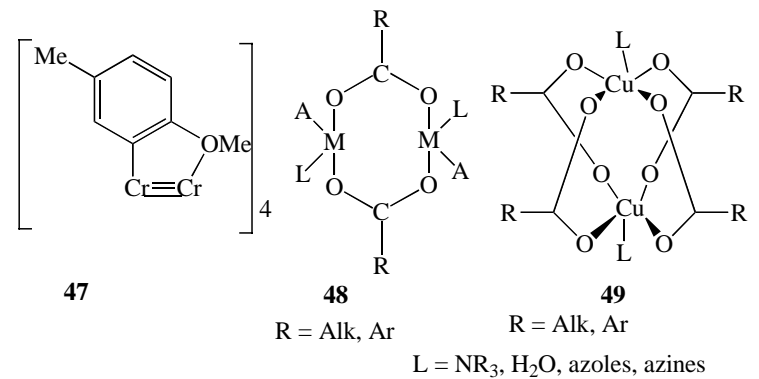


In relation with the problem of synthesis of molecular magnetics, carboxylate complexes 48 and 49 (shape of "Chinese lantern" $[5,7,8,10,14])$ are attractive for researchers. Complexes with intramolecular bridges 50-53 [14] are wellknown, in particular binuclear complexes with NCS fligands $\mathbf{5 0}[7,10,14]$.
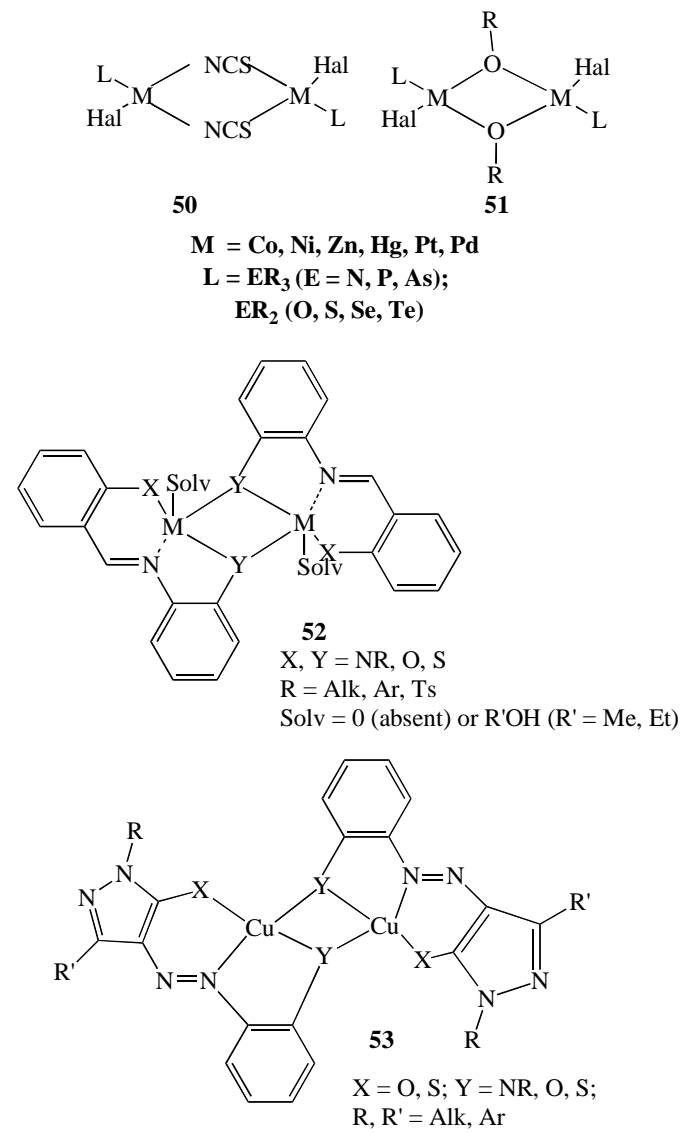

\section{Metalloligand Complexes [14]}

Long ago (beginning of 1960th [14]), a possibility of metal complexes to take part as ligands (metalloligands) is known, forming di- and oligonuclear structures in expenses of electron-donor coordinatively unsaturated fragments, for example 54-57.

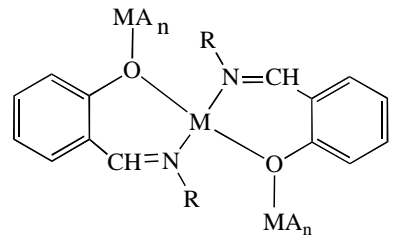

54

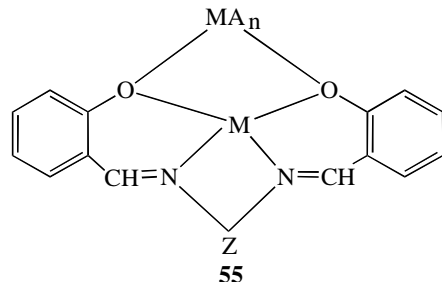

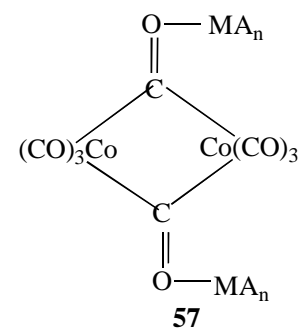

\section{Clathrochelates}

Metal dioximates 58, intensively studied by Chugaev, are classic metalloligands; using them as precursors, mostly trinuclear complexes 59, known as a clathrochelates are obtained $[25,26]$.

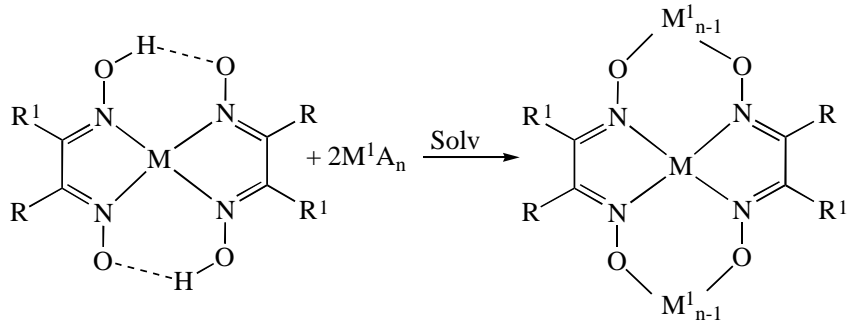

58

59

Synthesis of Coordination Compounds [14, 27-46]

Direct Interaction of Precursors [14, 27-29]

Reactions of Ligating Compounds and Metal Salts

As a result of interaction of these reagents, mostly in non-aqueous organic solvents (alcohols, hydrocarbons and their halide derivatives, etc.), all types of above indicated metal complexes are formed.

\section{Molecular Complexes}

$$
\mathrm{mL}+\mathrm{nMA}_{\mathrm{p}} \rightarrow \mathrm{L}_{\mathrm{m}} \cdot\left(\mathrm{MA}_{\mathrm{p}}\right)_{\mathrm{n}}
$$

Azole complexes 60 are being intensively studied [22].

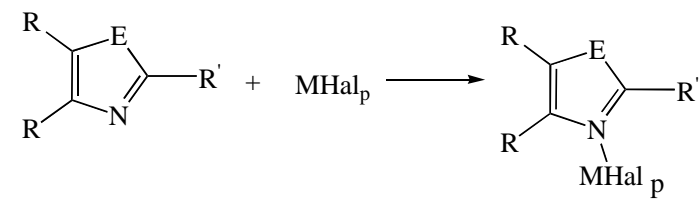

$\mathrm{R}=\mathrm{H}$, Alk, Ar; $\mathbf{R}^{\prime}=$ Alk, Ar, $\mathrm{NH}_{2}$

60

\section{Chelates [14-16, 33-36]}

As an example, we selected azomehine chelates, having, depending on donor atom $(\mathrm{X})$, trans- $(\mathbf{6 1})$ or cis- (62) structures $[14,15]$.

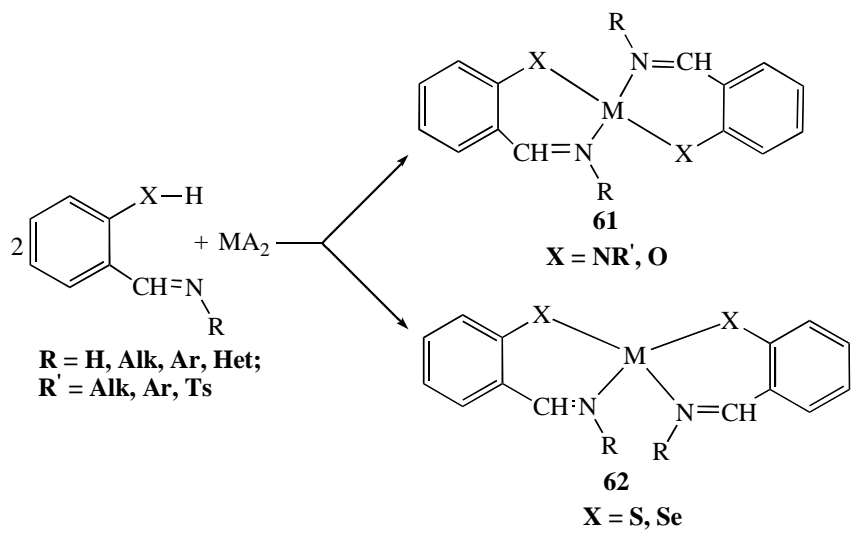

CMB [14, 29]

The oldest complexes of this type are $\pi$-complexes of ethylene series with dichlorides of platinum metals, for instance 63. 


$$
2 \mathrm{R}_{2} \mathrm{C}=\mathrm{CR}_{2}+\mathrm{PdCl}_{2} \longrightarrow \mathrm{CR}_{63}
$$

The syntheses 64 [29] are classic for obtaining sandwich compounds $\mathbf{3 1}, \mathbf{3 2}$.

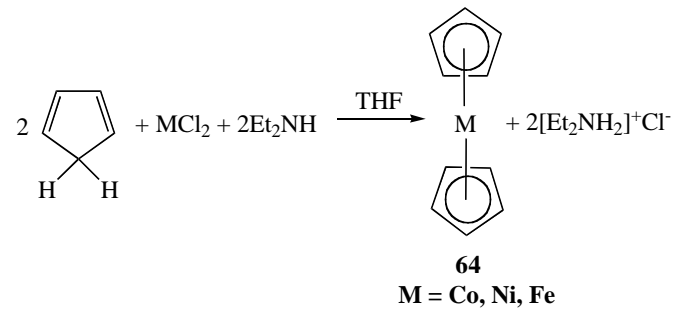

We note that, as a result of a direct interaction 65 of precursors, unpredictable structures were formed, for example tetranuclear complex 66 [37].
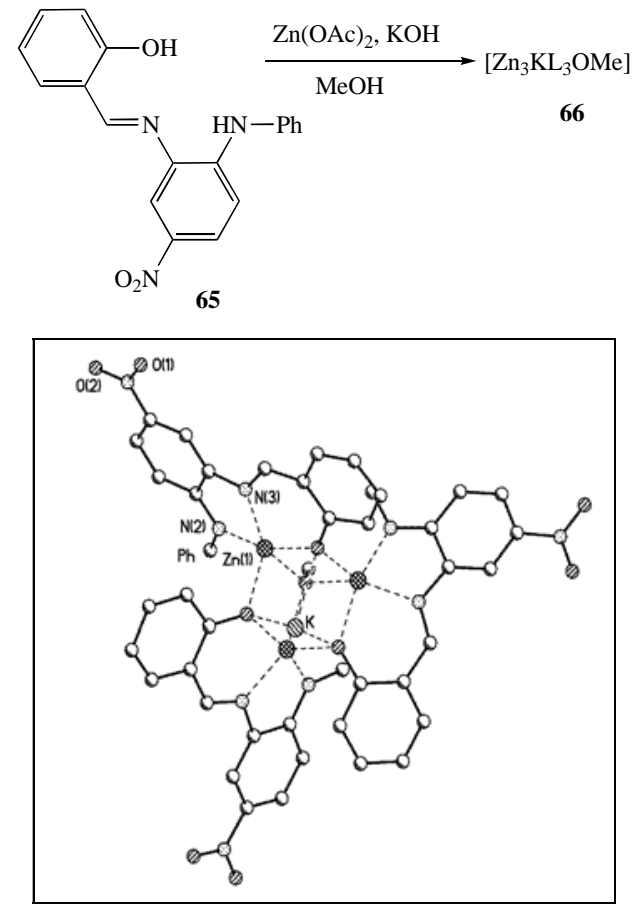

Molecular structure of the complex 66

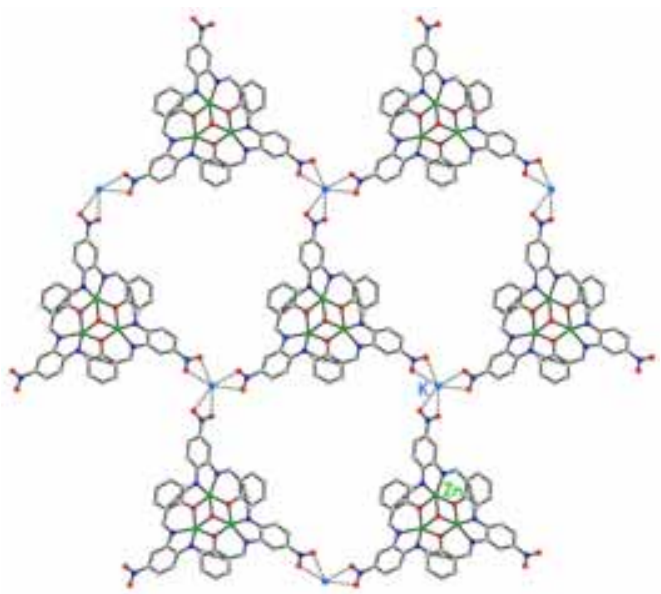

Crystal structure of the complex 66

\section{Template Synthesis $[5,14,15,30-34]$}

This type of synthesis is based on the formation of ligand on a metal matrix, e.g. Schiff bases from aldehydes 67 and primary amines. This route is used for obtaining acyclic $\mathbf{6 8}$ and cyclic 69 complexes of azomethines [13(Vol. 2), 14, 33, 36].

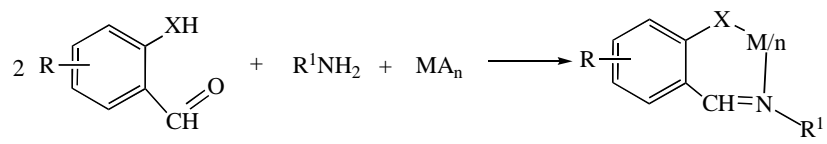

67

68

$\mathrm{X}=\mathrm{NR}^{2}, \mathrm{O}, \mathrm{S} ; \mathrm{R}=\mathrm{H}, \mathrm{Hal}, \mathrm{NO}_{2} ; \mathrm{R}^{1}=\mathrm{H}, \mathrm{Alk}, \mathrm{Ar} ; \mathrm{R}^{2}=\mathrm{Alk}, \mathrm{Ts} ; \mathrm{A}=\mathrm{OAc}, \mathrm{Hal}, \mathrm{NO}_{3}$

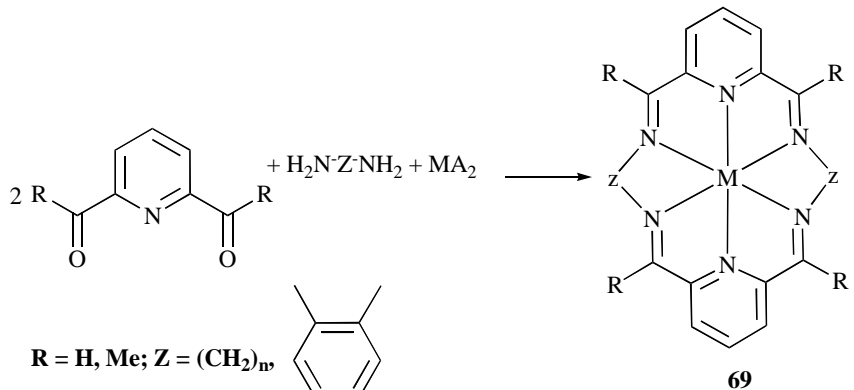

A similar technique is applied for synthesis of coordination compounds of crown-ethers 70 [38], tetrapyrrole derivatives of porphyrins 71 and phthalocyanines 72 [13, 39].

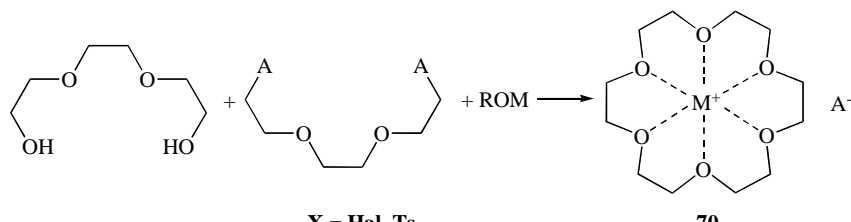

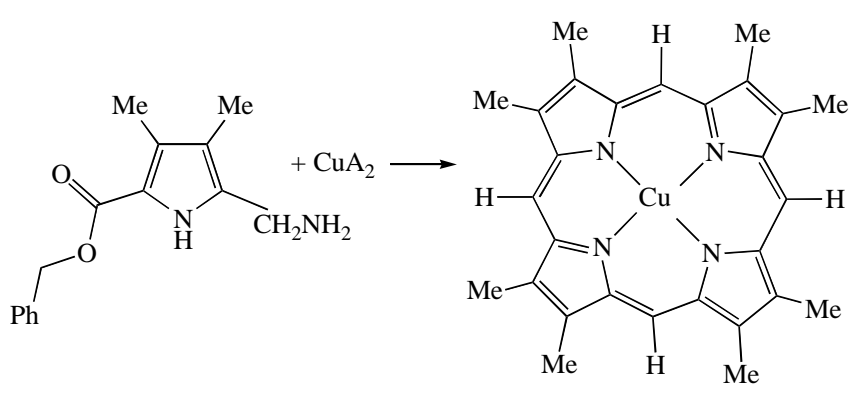

71

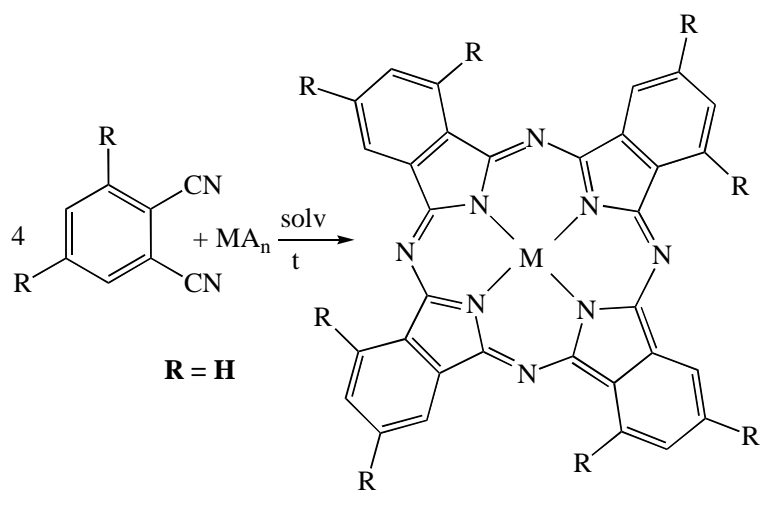


Rare structures are sometimes formed in the conditions of template syntheses, for instance $\mathbf{7 3}$ [40].

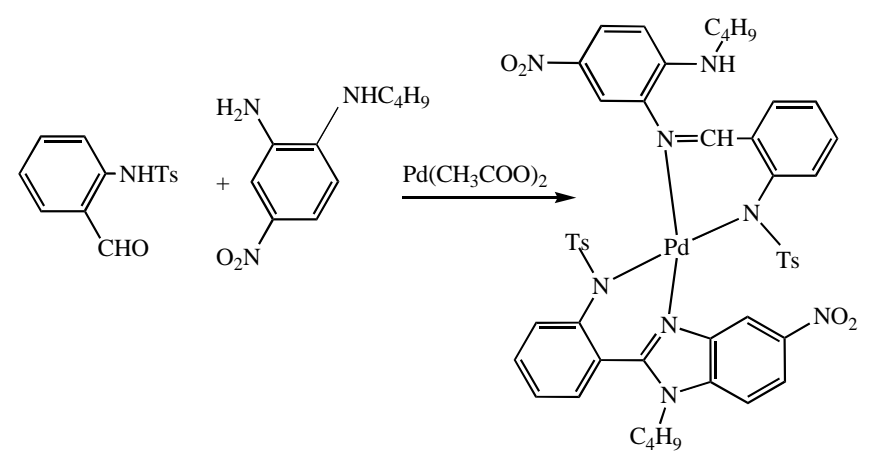

73

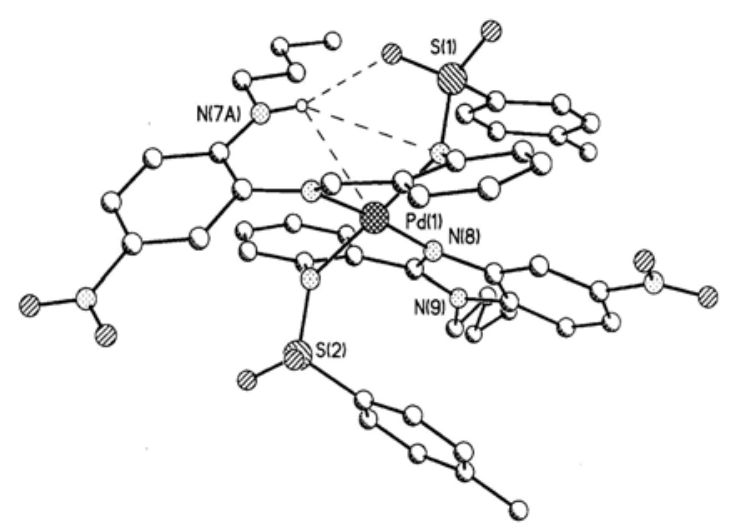

\section{Structure of the chelate 73}

It was established the interaction of $o$-tosylaminobenzaldehyde with aniline derivatives on a palladium matrix leads to formation the complex $\mathbf{7 3}$ with two different form of the same ligand. The structure $\mathbf{7 3}$ was proved by X-ray diffraction: one ligand is azomethinic, another one exists in benzimidazole form.

\section{Ligand Exchange [14]}

\section{Molecular Complexes}

This method is known as far back as from Werner's experiments, for instance for obtaining 74 [6].

$$
\left[\mathrm{Ni}\left(\mathrm{H}_{2} \mathrm{O}\right)_{6}\right] \mathrm{Cl}_{2}+6 \mathrm{NH}_{3} \rightarrow\left[\mathrm{Ni}\left(\mathrm{NH}_{3}\right)_{6}\right] \mathrm{Cl}_{2}+6 \mathrm{H}_{2} \mathrm{O}
$$

\section{4}

Especially widely this technique is applied to synthesize metal carbonyl complexes having distinct compositions $\mathbf{7 5}$ and 76 [29].

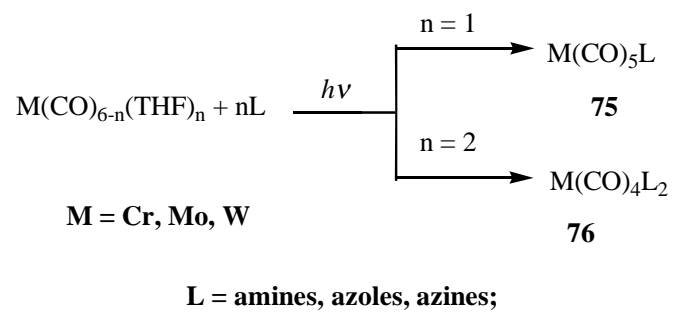

In this respect, use of this route for syntheses of triphenylpyridine $77(\mathrm{E}=\mathrm{N})$, phospho- $77(\mathrm{E}=\mathrm{P})$ and arseno - 77 $(\mathrm{E}=\mathrm{As})$ benzene compounds seems attractive $[14,22]$.<smiles>CC(=O)P(c1ccccc1)c1cc(-c2ccccc2)cc(N=[W]=O)c1-c1ccccc1</smiles>

\section{Chelates}

The method of ligand exchange is used for obtaining chelates starting from low-soluble salts, for instance palladium chloride $\mathbf{7 8}$ or from $\mathrm{NH}$-ligands (acetylacetonate method) 79 [14].

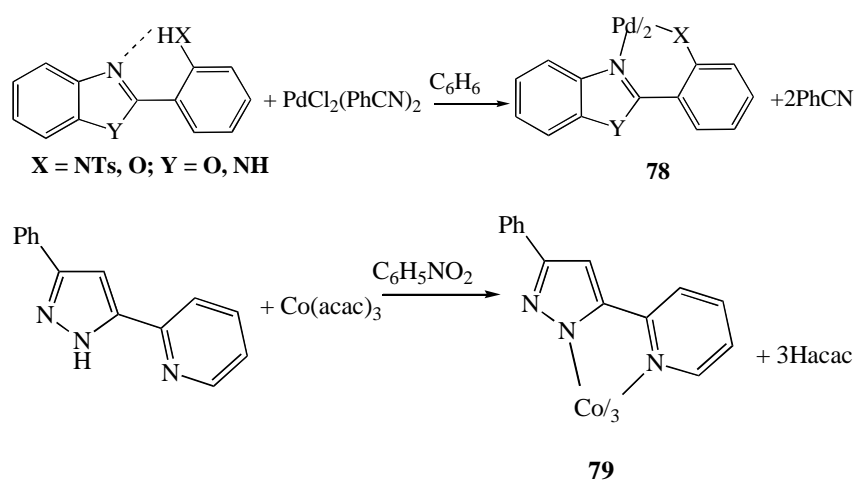

$\pi$-Complexes

Complexes of classic heterocycles, such as pyrrol $\mathbf{8 0}$ or pyridine 81, were obtained by exchange of the carbonyl ligand [22].
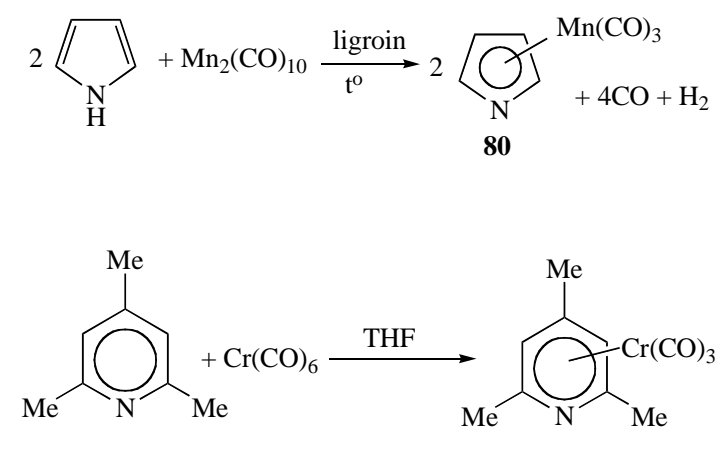

81

\section{Metal Exchange}

\section{Chelates}

This technique is applied for obtaining chelates of chalcogen-azomethines $\mathbf{8 2}$ and $\mathbf{8 3}$ from low-stable Schiff bases or 2-phenylazoles [14, 41].

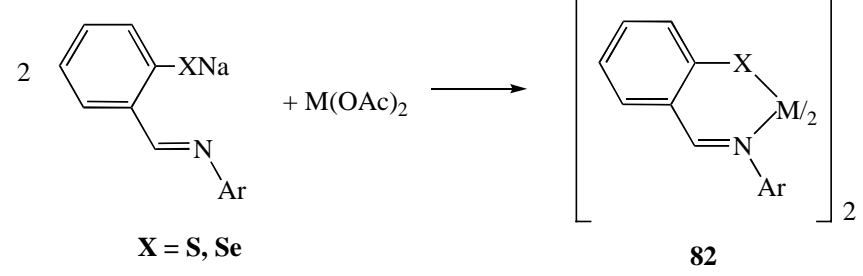




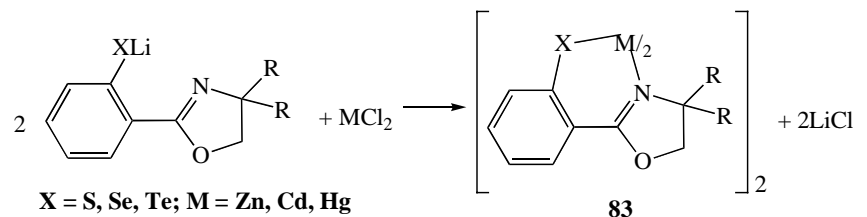

\section{Direct Syntheses [14, 42]}

\section{Gas-Phase Synthesis (Cryosynthesis)}

This technique is a part of the method of a direct interaction of precursors and it is based on the use of elemental (zero-valent) metals as complex-formers.

\section{Molecular Complexes}

Such syntheses are carried out in vacuum equipment on surfaces cooled with liquid nitrogen or helium. This method is widely applied for obtaining metal carbonyls 84 .

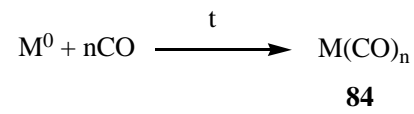

$\mathrm{M}=\mathrm{Co}, \mathrm{Mn}, \mathrm{Cr}, \mathrm{Fe}, \mathrm{Ni}, \mathrm{Pd}, \mathrm{Pt}, \mathrm{Rh}, \mathrm{Cu}, \mathrm{Ag}, \mathrm{Ir}, \mathrm{Eu}, \mathrm{Nd}$

\section{Chelates}

At present, only a few examples are known for obtaining chelate structures $\mathbf{8 5}$ in gas-phase synthesis conditions [42]. More frequently such structures are formed in the conditions of tribo(mechano)synthesis [42].

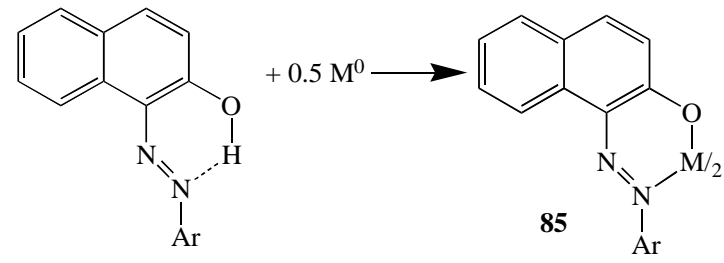

\section{$\pi$-Complexes}

Gas-phase synthesis is widely applied in syntheses of $\pi$-complexes of heterocycles, for example pyridine $\mathbf{8 6}$ and phosphabenzene $\mathbf{8 7}$ sandwiches. Using classic chemical routes, such compounds cannot be obtained [14, 42].

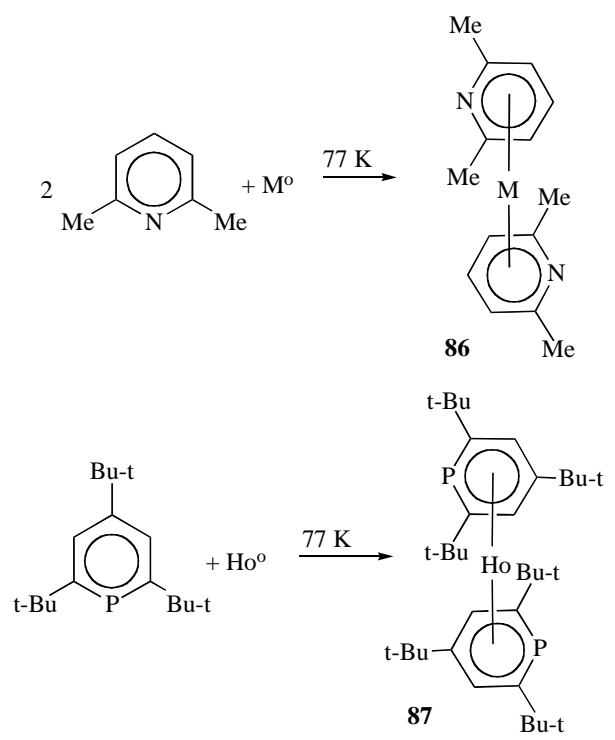

\section{Electrosynthesis (ES) [13(Vol. 1); 14, 42]}

This technique of the direct synthesis, which is being developed from 1970, is an important synthetic method in modern coordination chemistry [43-45]. It is based on an anodic dissolution of elemental metals (platinum plate is usually used as a cathode). Reactions are carried out in nonaqueous polar solvents (alcohols, acetonitrile, DMSO, DMF, etc.), generally at $20-50^{\circ} \mathrm{C}$, using tertiary ammonium salts as conducting additives. Industrial equipment exists, modified with ultrasound and/or UV-irradiation for activation of electrosynthetic processes. The advantages $[44,45]$ of the ES are obtaining only anionless complexes, friendly synthetic conditions and a possibility, in some cases, of isolation of intermediate products.

\section{Chelates}

Some examples of electrosyntheses, leading to chelates 88-90, are represented below [14, 42-45]. A template electrosynthesis route was offered [46], in which, under soft conditions, intermediate products $\mathbf{8 8}$ and $\mathbf{8 9}$ can be isolated, together with the final compound $\mathbf{9 0 .}$

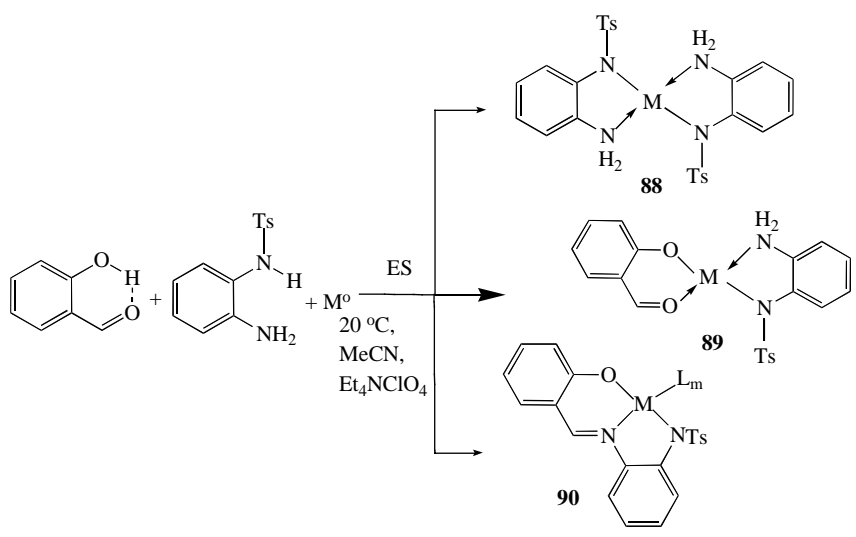

Ts $=-\mathrm{SO}_{2} \mathrm{C}_{6} \mathrm{H}_{4} \mathrm{Me}-\mathrm{p} ; \mathrm{L}=\mathrm{H}_{2} \mathrm{O}, \mathrm{MeCN} ; \mathrm{M}=\mathrm{Ni}, \mathrm{Cu}, \mathrm{Zn}$

The ES had played an important role in obtaining coordination compounds with N,O,S- and N,O,Se-ligand environment. Here, the reaction of electrochemical cleavage of S-S and Se-Se bonds was used, discovered by Tuck [42, 44]. In particular, on the basis of formally tetradentate ligand, the complexes 91 and $92(X=S, S e)$ were electrochemically synthesized.

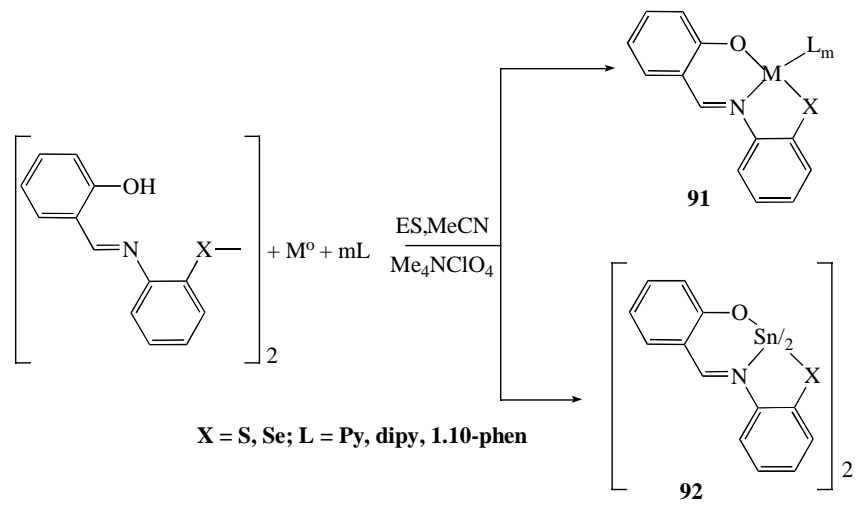

Among other electrochemically obtained chelates, classic $\beta$-diketonates $93(X, Y=O)$ and salicylaliminates 94 and 95 were reported $[14,42]$. 
<smiles>[R]C1=C[Y8](=N)OC([R])=C1[R]</smiles>

$\mathrm{n}=\mathbf{2 - 4}$; M = Cu; Cd, Zn; Al, In; Ti, Zr, Hf; $\mathrm{V}, \mathrm{Nb}, \mathrm{Ta}$; $\mathrm{Cr}, \mathrm{Mo}$; Mn; Co, Ni, Fe; Ce, Dy, U, Th. Solv = MeCN, ROH, THF, Py, diglym

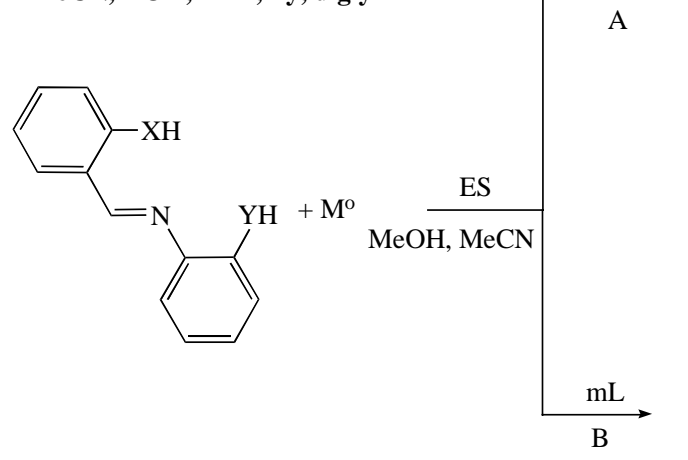<smiles>[R]C1=C([R])OC2(O1)OC([R])=C([R])O2</smiles>

$\mathrm{R}$

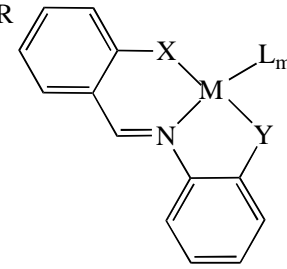

94 L = Py, dipy, 1.10-phen

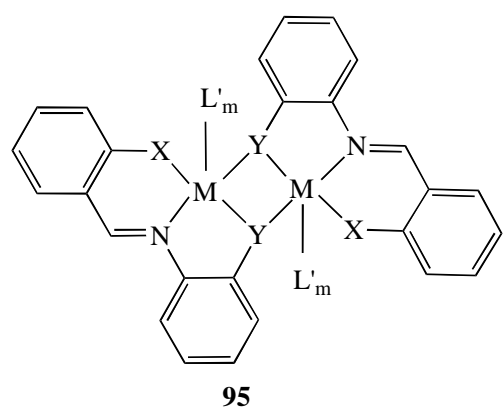

$\mathbf{L}^{\prime}=\mathrm{MeOH}, \mathrm{MeCN}$
Other synthetic techniques (microwave, biphasic, tribochemical, ultrasonic, hydrothermal, and sol-gel) for obtaining coordination compounds also exist and described in [13], but they have still a limited application in coordination chemistry. Thus, MW-heating has been usually applied for obtaining inorganic materials; ultrasonic treatment has been used more widely in synthesis of metal complexes (examples of obtained compounds: carbonyls, diene or Gringard complexes). An example of hydrothermal synthesis is obtaining $\left[\mathrm{Cu}\left(2-\mathrm{IC}_{7} \mathrm{H}_{4} \mathrm{~N}_{2}\right)\right]_{n}$ from $\mathrm{CuI}$ and benzimidazole. Sol-gel processes starting from metal alkoxides can lead to dimeric species such as, for example $(\mathrm{RO})_{3} \mathrm{TiOSi}(\mathrm{OR})_{3}$. Biphasic reactions takes place in immiscible phases (solvents) and are widely used in catalysis [13].

\section{Reactivity of Coordination Compounds [13, 47-50]}

Reactivity of metal complexes is an important area of coordination chemistry [47-50], including reactions on coordinatively-unsaturated donor centers 52, 59 [14, 17, 25, 26] or metals complex-formers $\mathbf{5 4 - 5 7}[14,41,42]$, as well as reactions of self-assembling, leading to various supramolecular structures [19-21]. Reactions of coordinated inorganic and organic ligands are of the high interest. In particular, in 1998-2007 reactivity of such ligands as nitriles (RCN) and oximes, coordinated to the ion Pt(IV) is intensively studied [50-62]. The main attention in these studies is given to the reactions of nucleophylic addition of various nucleophiles on the carbon atom of triple $\mathrm{CN}$-bond of the nitrile fragment, whose electrophylic activation was reached because of its coordination to $\mathrm{Pt}(\mathrm{IV})$ 96. According to Scheme 1, both mono- (route a, b, c, d) and bifunctional (ambidentate) (route e, f) nucleophylic molecules can be used as reagents. Reactions take place in soft conditions and with high grade of selectivity, allowing generate new - imino (a, b, c, e), amidino (f) and heteroarylamidine (d) ligands, major part of which is inavailable in a classic organic synthesis, in the internal coordination sphere of the $\operatorname{Pt}(\mathrm{IV})$ ion.

The most interesting work, on the point of view of the data above on reactions between various metals and Schiff bases, is the study of reactivity of various hydrazoneoximes with propionitrile, coordinated to Pt(IV) 97 (Scheme 2) [58].

This work shows a real possibility of programmed synthesis of a platinum-containing ligand (salicylalhydrazone

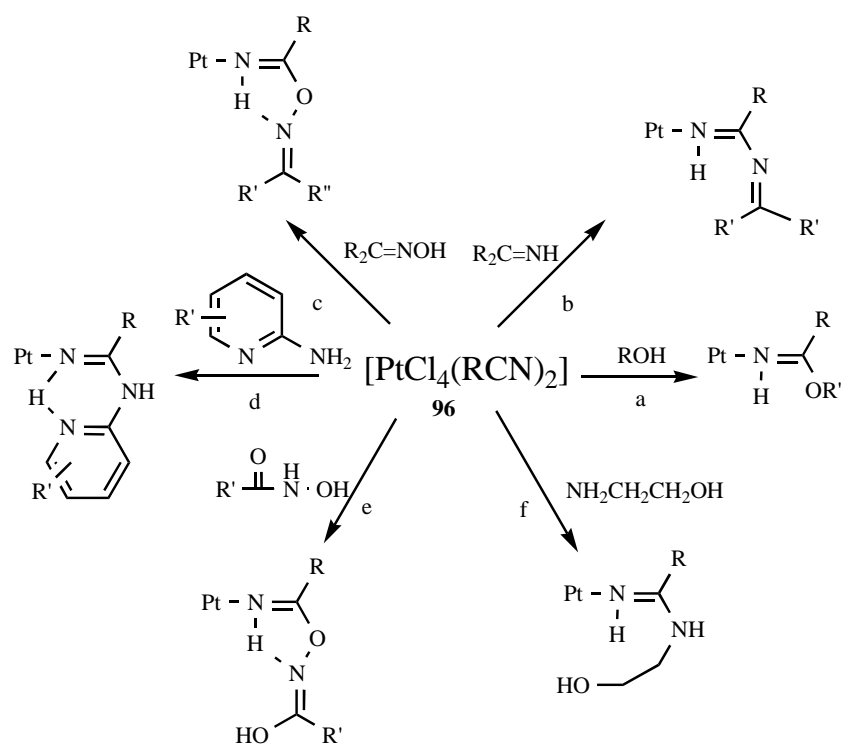

Scheme 1. Reactions of nucleophylic addition of various substrates to the coordinated nitriles. 


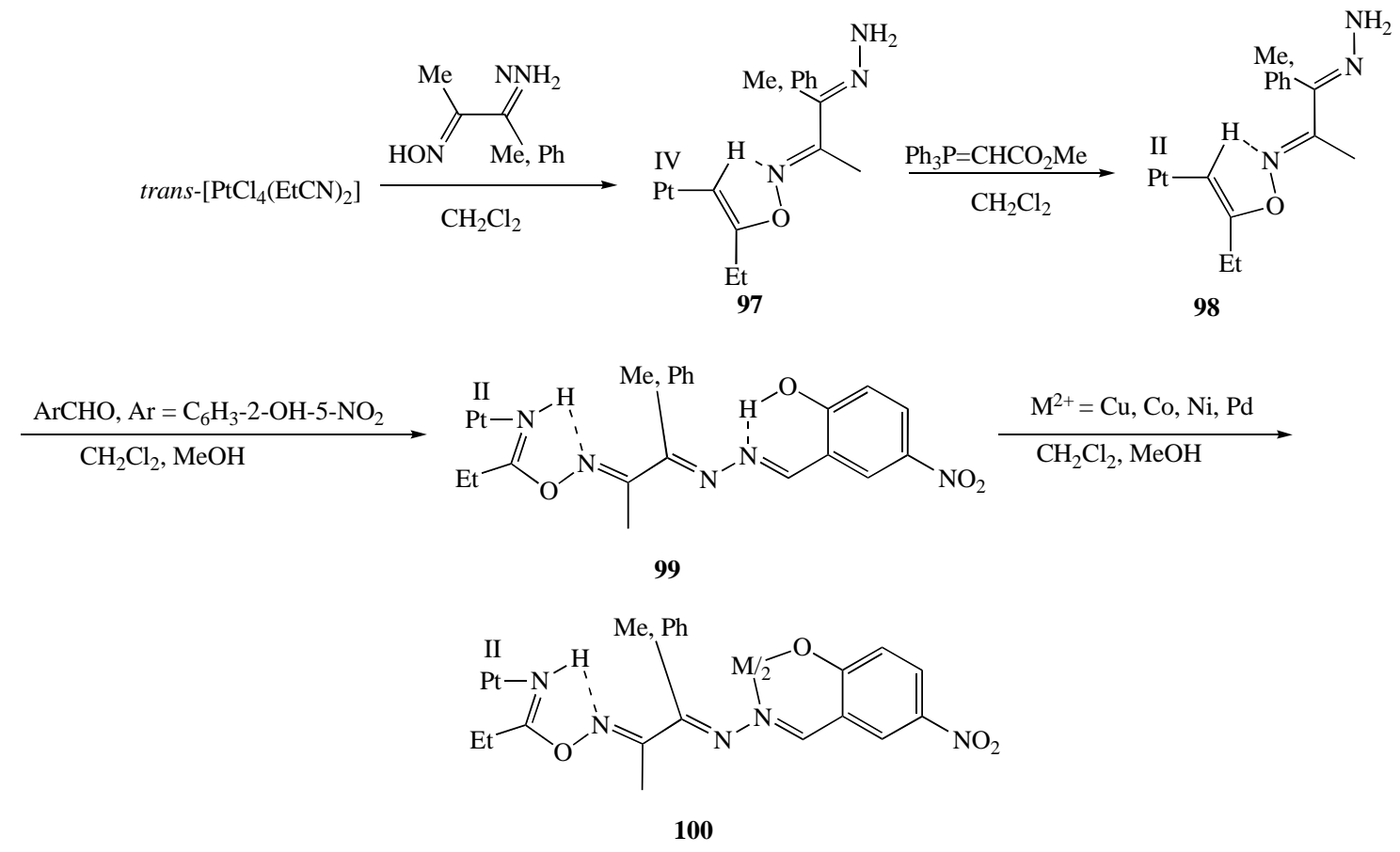

Scheme 2. Synthesis of Pt-containing metalloligand and its complexes.

derivative) as a result of a series of subsequent transformations. The first step represents a selective nucleophylic addition of the ambidentate base (oximehydrazone 97) on the oxime group accompanying by conservation of free periph- copper complexes of bis-thiosalicylidenethylenediamine and its analogues of the type 101. Later on ([67] and refs. therein) it became possible to obtain models of pyrazolethioazomethine complexes, showing EPR- and electronic

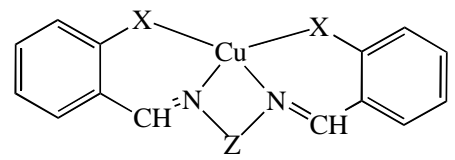

101

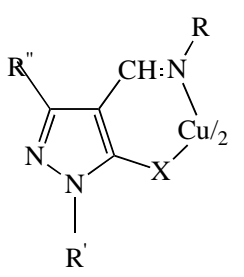

102

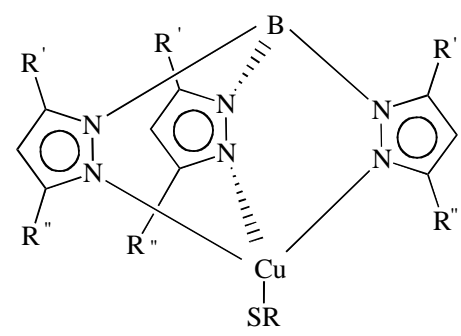

103

$\mathrm{X}=\mathrm{S}, \mathrm{Se} ; \mathrm{Z}=\left(\mathrm{CH}_{2}\right)_{\mathbf{n}}, \mathrm{n}=1-6 ; \mathrm{R}=\mathrm{Alk}, \mathrm{Ar} ; \mathrm{R}^{\prime}, \mathrm{R}^{\prime \prime}=\mathrm{Alk}$

eral amino group of the hydrazine fragment. In the second stage, a reduction of the product 97 takes place resulting obtaining a soluble isostructural compounds of $\mathrm{Pt}(\mathrm{II}) \mathbf{9 8}$, which further enters in Schiff condensation reaction with 5-nitrosalicylaldehyde, leading to the salicylalhydrazone derivative 99, which is capable to form metal complexes (Scheme 2, structure 100). All described compounds are characterized by elemental analysis data, $\mathrm{FAB}^{+}$-mass spectra, IR, ${ }^{1} \mathrm{H},{ }^{13} \mathrm{C}\{\mathrm{H}\},{ }^{195} \mathrm{Pt}$ NMR spectroscopies. X-Ray diffraction data are available for the 97-99.

\section{Complexes of Bioligands (Biomimethics [5, 13(Vol. 8); 63-69])}

A whole volume of modern coordination chemistry [13(Vol. 8)] is devoted to the complexes of bioligands. Among them, we note copper-chalcogene chelates [63, 64, $66,67]$, modeling active centers of blue copper proteins 101103. In early studies $[63,64]$, there were cross-linked $(\mathrm{Z})$ absorption spectral parameters of blue copper proteins $\mathbf{1 0 2}$. All these parameters, as well as redox-potential, were observed on the model of tris(pyrazolyl) borate copper complexes 103 [68].

Active centers of blue copper protein

Complexes 104 и 105 are well-known [13(Vol. 8)]<smiles>[Z]CN(/N=C/c1ccccc1[X])/N=C/c1ccccc1[X]</smiles>

104

Carriers and activator for small molecules $\left(L=\mathbf{O}_{2}, N_{2}\right)$<smiles>[Y19]=C1OCCOCCOCCOc2ccccc2OCCO1</smiles>

105

sionophors (crown-ether complexes) 
Other models are presented by formulae 104-106. It is known that $106(\mathrm{M}=\mathrm{Mg})$ is chlorophill providing respiration function of plants, $106(\mathrm{M}=\mathrm{Fe})$. Vanadium coordination compounds are well-known in bioinorganic chemistry $[5,13,69]$, whose most important function is nitrogen fixation (vanadium nitrogenase, FeV-protein). A lot of information on the coordination chemistry of biologically important carbohydrates is discussed in reviews [69-71].

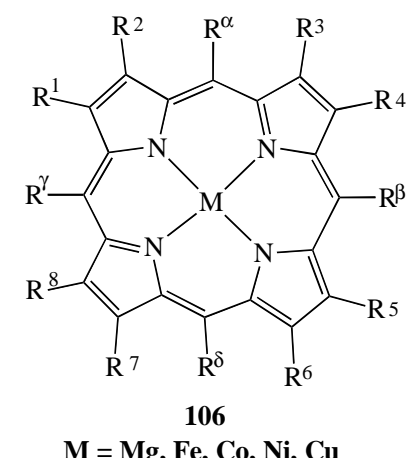

\section{Competitive Coordination [14, 72-76]}

Capacity of di- and polidentate ligands to react with metal ion through distinct donor centers was named as competitive coordination [72]. Such ligands are ambidentate [74, 75].

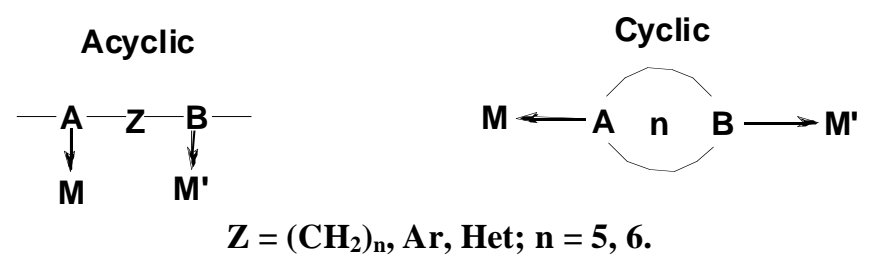

This is a extended variant of bonding ligand isomery, discovered by Jorgensen as far back as in 1894 on the example of a distinct binding of the $\mathrm{NO}_{2}$ anion [11]:

$$
\begin{array}{ccc}
{\left[\mathrm{Co}(\mathrm{ONO})\left(\mathrm{NH}_{3}\right)_{5}\right] \mathrm{Cl}_{2} \stackrel{\mathrm{t}}{\longrightarrow} \underset{\text { Nitrite, orange }}{[}\left[\mathrm{Co}\left(\mathrm{NO}_{2}\right)\left(\mathrm{NH}_{3}\right)_{5}\right] \mathrm{Cl}_{2}} \\
\text { nitro, yellow }
\end{array}
$$

Eight coordination modes 107-114 for $\mathrm{NO}_{2}$ anion were examined [7]. We note that, according to X-ray diffraction data, 107-110 are the most common modes.

$$
107
$$

108<smiles>[M]O[N+]([M])O[M]</smiles><smiles></smiles>

109<smiles>[M]C1O[N+]([M])O1</smiles>

113<smiles>[M]ON=O</smiles>

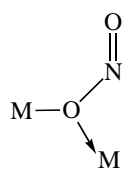

110
Explanation of competitive coordination was given according to the classic HSAB principle ([72,73] and refs. therein). Ideas about "hard" and "soft" acids and bases were introduced by R. Pearson in 1963 and at present are widely used in various aspects of coordination chemistry [73]. Competitive coordination has been studied on many ambidentate anions, among which pseudo-halide anions 115-124 should be noted [14, 74, 77]. When $X=O$, both centers are hard; in case of $\mathrm{X}=\mathrm{S}$, Se, a hard-soft ligand system is formed, whose coordination is proved using HSAB principle [14, 72-76].

$$
\begin{aligned}
& \mathrm{M}-\mathrm{N}=\mathrm{C}=\mathrm{X} \quad \mathrm{M}-\mathrm{X}-\mathrm{C} \equiv \mathrm{N} \quad \mathrm{M}-\mathrm{X}-\mathrm{C} \equiv \mathrm{N}-\mathrm{M}^{\prime} \\
& 115 \quad 116 \quad 117
\end{aligned}
$$

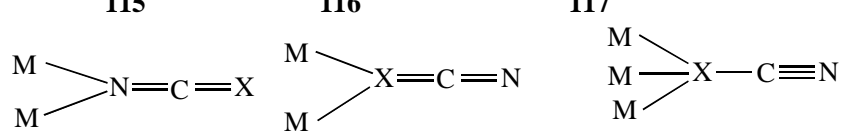

$$
\begin{aligned}
& 118 \quad 119 \quad 120 \\
& \mathrm{M}-\mathrm{N} \equiv \mathrm{C}-\mathrm{X} \underset{\mathrm{M}^{\prime}}{\mathrm{M}^{\prime}} \quad \mathrm{M}-\mathrm{M}=\mathrm{C}=\mathrm{X}-\mathrm{M}^{\prime} \\
& 121 \\
& \mathrm{M}-\mathrm{N} \equiv \mathrm{C}-\mathrm{X} \underset{\mathrm{M}^{\prime}}{<} \underset{\mathrm{M}}{\mathrm{M}^{\prime}} \stackrel{\mathrm{M}}{\mathrm{M}_{\mathrm{N}}} \mathrm{N}=\mathrm{C}=\mathrm{X} \underset{\mathrm{M}^{\prime}}{\mathrm{M}^{\prime}} \\
& 123 \\
& \mathrm{X}=\mathrm{O}, \mathrm{S}, \mathrm{Se}
\end{aligned}
$$

For azine complexes 125-130, an $\mathrm{N}$-atom is hard, meanwhile the heteroaromatic $\pi$-system is soft $[5,14]$.

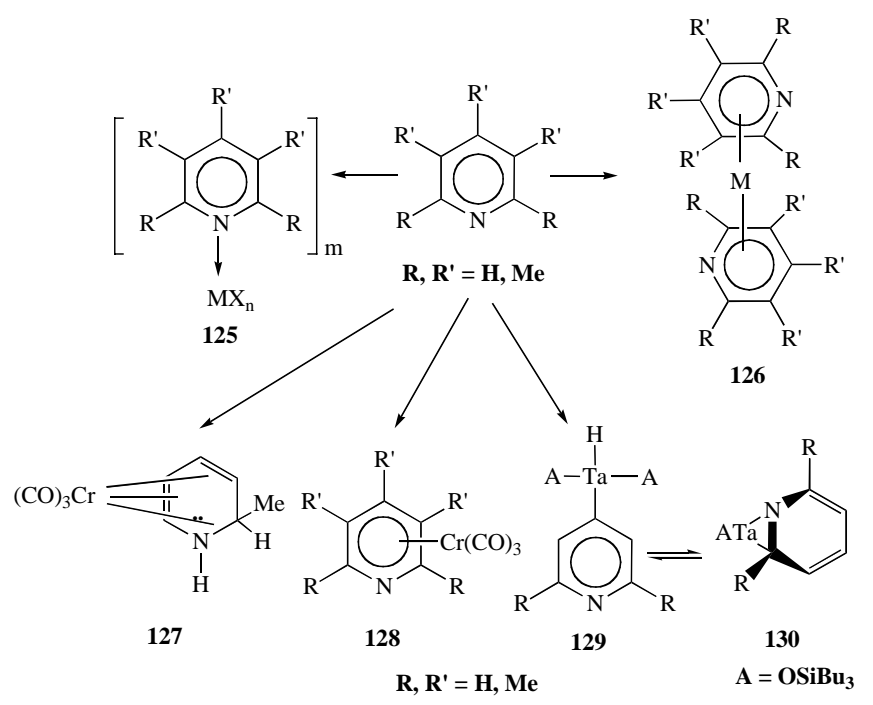

In this case, independently on the hardness or softness of a complex-former, the $\mathrm{N}$-atom could form a coordination bond, but soft acids prefer to be coordinated by a soft $\pi$-system of pyridine 126, 128 .

Nobel laureate E.O. Fisher made a first attempt to coordinate heteroaromatic $\pi$-system of pyridine. In 1964 he considered that obtained the complex of the type $\mathbf{1 2 8}$ on the basis of $o$-monomethylpyridine. However, later on (in 1967) two additional protons were detected in ${ }^{1} \mathrm{H}$ NMR spectra, so it had to inscribe the structure of $\sigma, \pi$-complex 127 to this compound. Then (in 1976), D. Lagovskii obtained a pyridine analogue of dibenzenechromium $\mathbf{1 2 6}$ by cryosynthesis technique; Biderman isolated the compound 128 creating additional spatial difficulties for the NB-atom [14]. Highly unexpectedly (in 1991), an equilibrium transformation 129-130 
was discovered, in which a carbene 129 and C,N 130 coordinated complexes take part $[5,78]$.

$\sigma-\mathrm{N}-$ Complexes 131 are typical for azoles [14, 22, 79, 80]. Bis-azole complexes of the type $\mathbf{1 3 2}$ have not yet been discovered, but a pyrazolcyclopentadienyl ruthenium complex 133 [14, 81] and imidazolecarbene compounds 134 [82] were isolated.

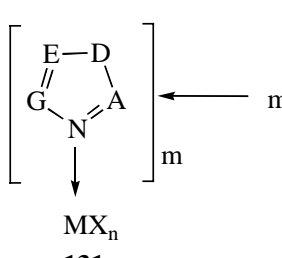

131

$\mathrm{A}, \mathrm{D}, \mathrm{E}, \mathrm{G}=\mathrm{CR}, \mathrm{N} ; \mathrm{R}=\mathrm{H}, \mathrm{Alk}, \mathrm{Ar}$

$$
\sigma \text {-complex }
$$

$\pi$-complex

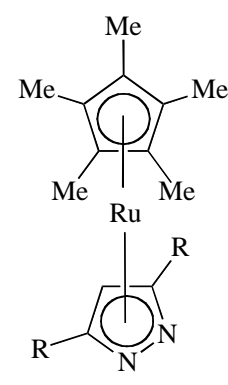

133

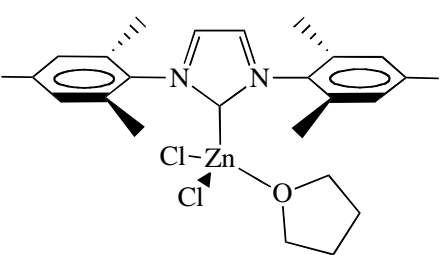

134
Competitive coordination is clearly observed in chelating ligand complexes. This is well-known that $\beta$-diketones form chelate structures of the type $\mathbf{1 3 5}$ with same inner-chelate bonds 136 [14]. At the same time, molecular chelates with completely conserved (non-deprotonated) ligand system are known, in which a diketone form $\mathbf{1 3 6}$ of the ligand is stabilized as a result of metal coordination. Various coordination modes of $\beta$-diketones and their analogues are discussed in monographs [14, 83] and reviews [75, 76]. One interesting example is a C-coordinated structure 137 [14].

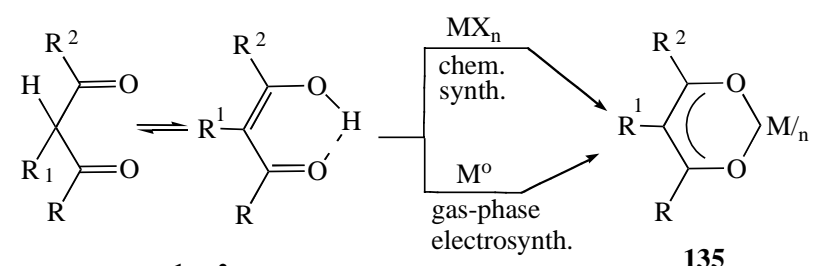

$\mathbf{R}, \mathbf{R}^{\mathbf{1}}, \mathbf{R}^{\mathbf{2}}=$ Alk, Ar, Het; $\mathbf{n}=\mathbf{2 - 4}$
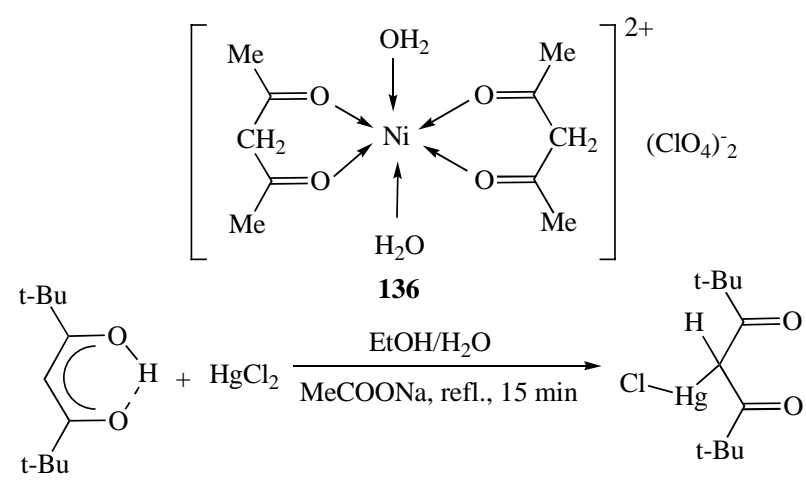

On the basis of 2-hydroxiazomethine ligands, a host of chelate salicylideniminates 138 was obtained [14, 15, 34-36, 84]. However, molecular complexes 139 are also known, where usually bidentate Schiff bases behave as monodentate O-donor ligands [14, 34, 84-86].
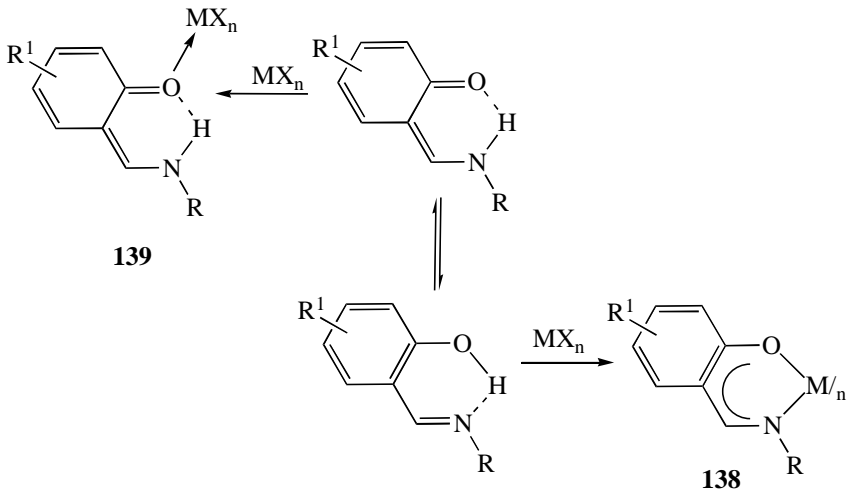

First data on these molecular complexes were reported in 1964, although a coordination mode was not determined 140. Unusual coordination on the oxygen atom in the $o$-hydroxynaphthalideneaniline complex with $\mathrm{ZnCl}_{2} 141$ was proved by $\mathrm{X}$-ray diffraction [85] and keto-amine tautomeric form of the ligand was established. Later on [86], an analogous structural situation was revealed for the complex of zinc dichloride with salicylidenaniline.

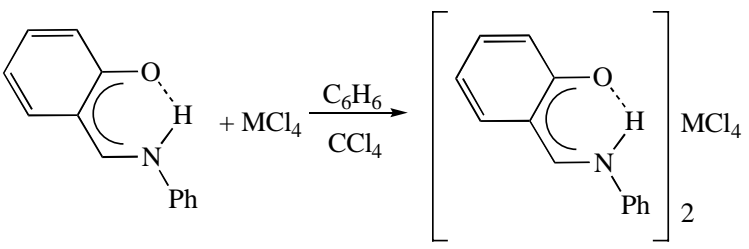

140

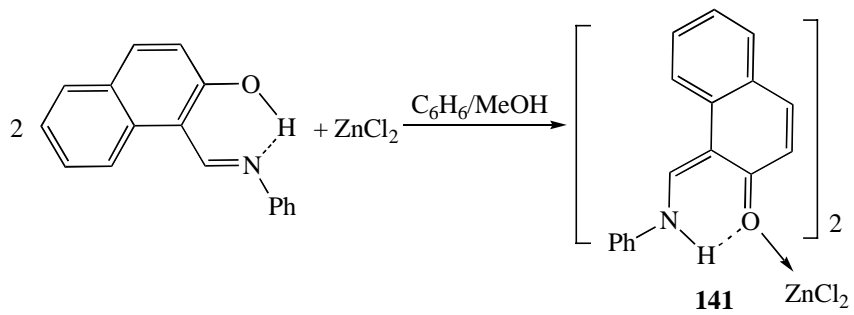

Discovery of inner-chelate isomery in a series of chelates of azo compounds [87-89] was important for coordination chemistry. It is accepted that two six-member metallocycles are present in such complexes. This is really observed for $o$-amine- 142 and hydroxy- 143 azo compounds. However, it was established by X-ray diffraction that an existence of of two 5- 144 or 5- and 6- 145 member metallocycles is typical for $o$-mercapthoazo compounds $[14,15,88,89]$. A similar inner-chelate tautomery is also observed for other chelates, for example in complexes of aromatic and heteroaromatic formazanes $[14,15]$.

\section{Polyfunctional Materials}

A central problem in modern coordination chemistry is application of its results in life, in particular by creation of new polyfunctional materials. This fact is directly emphasized in the second issue of [13], whose two volumes ( 8 and 


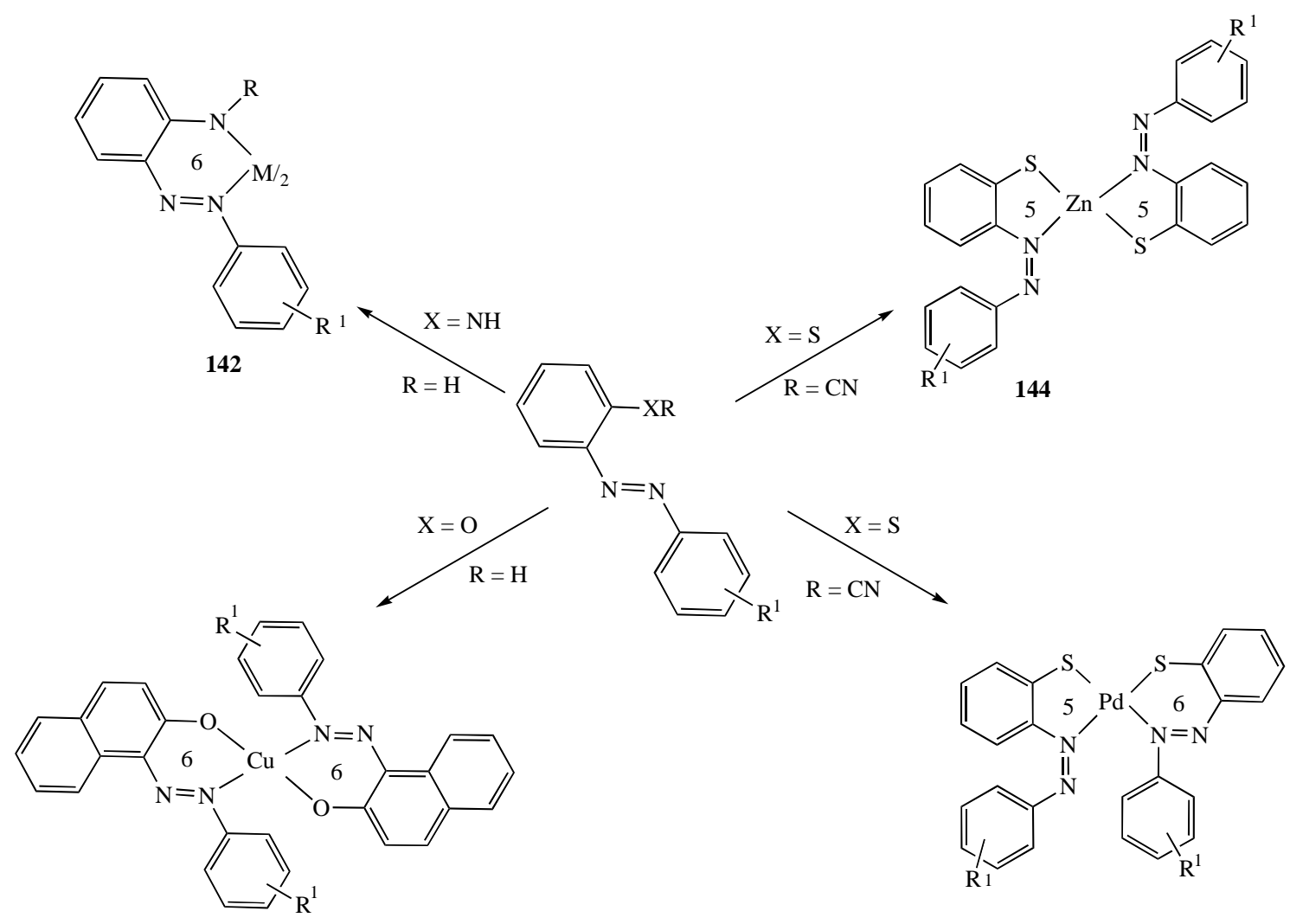

9) are dedicated to biocoordination chemistry and applications of coordination compounds, respectively. A considerable role of metal complexes in creation of new materials is noted in a series of special issues, for instance [90-94]. Here we will describe some important examples of use of coordination compounds.

Among magnetoactive complexes, the most interest is caused by those coordination compounds which possess ferromagnetic exchange interactions, in particular metal cyanides 146. The metal complex of Prussian blue 147, known from 1704 was one of the first (1967) ferromagnetic [95]. On the basis of cyanides of various metals, a series of hightemperature ferromagnetics 148 [95] were obtained, as well as photoactive magnetic materials (spin-crossover complexes [96]).

$\mathrm{M}_{\mathrm{m}}\left[\mathrm{M}_{\mathrm{n}}(\mathrm{CN})_{6}\right] \cdot \mathrm{pH}_{2} \mathrm{O} ; \quad-\mathrm{M}-\mathrm{C} \equiv \mathrm{N}-\mathrm{M}-; \quad \mathrm{Fe}_{4}\left[\mathrm{Fe}(\mathrm{CN})_{6}\right]_{3} \cdot 14 \mathrm{H}_{2} \mathrm{O}$ 146 147

$$
\begin{gathered}
\mathrm{M}_{3}{ }^{2+}\left[\mathrm{Mn}(\mathrm{CN})_{6}\right]_{2} \quad \mathrm{M}_{3}\left[\mathrm{Cr}(\mathrm{CN})_{6}\right]_{2} \\
\mathbf{M}=\mathbf{V}, \mathbf{C o}, \mathbf{M n}, \mathbf{C r}, \mathbf{N i}, \mathbf{C u} ; \mathbf{T c}=\mathbf{9 - 2 0} \mathbf{K} \\
\mathrm{V}^{2+}{ }_{0.42} \mathrm{~V}^{3+}{ }_{0.58}\left[\mathrm{Cr}^{3+}(\mathrm{CN})_{6}\right]^{3-}{ }_{0.86} 2.8 \mathrm{H}_{2} \mathrm{O} \quad \mathbf{T c}=\mathbf{3 1 5} \mathbf{K}
\end{gathered}
$$

148

Famous magnetochemist O. Kahn prepared the compounds with predictable magnetic properties on the basis of azomethine complexes [13(Vol. 2)]. Changing a series of metals, his group has obtained ferro- (positive exchange parameter) and antiferromagnetic complex compounds 149, 150. Similar complexes $\mathbf{1 5 1}$ are also ferromagnetic.

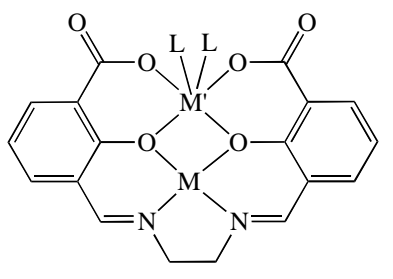

149

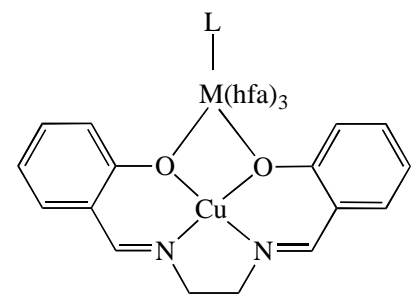

150

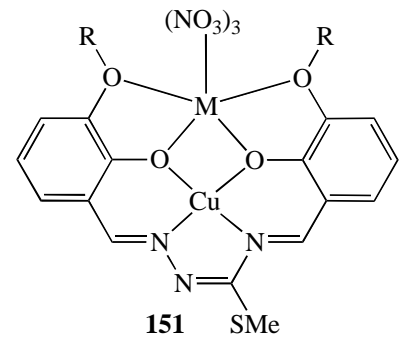

$\mathrm{R}=\mathrm{Me}, \mathrm{Et} ; \mathrm{M}=\mathrm{Ce}, \mathrm{Gd}$
$\mathrm{M}, \mathrm{M}^{\prime}=\mathrm{Cu}, \mathrm{Fe}, \mathrm{VO} ; \mathrm{L}=\mathrm{H}_{2} \mathrm{O}, \mathrm{MeOH}$

Cu - VO $\quad J=+118$ cm$^{-1}$

$\mathrm{Cu}-\mathrm{Cr} \quad \mathrm{J}=+115 \mathrm{~cm}^{-1}$

$\mathrm{Cu}-\mathrm{Fe} \quad \mathrm{J}=-\mathbf{1 0 5} \mathrm{cm}^{-1}$

Hhfa = hexaftoroacetylacetone<smiles>Cn1ccnc1</smiles>

$\mathbf{M}=\mathbf{G d}, \mathbf{Y}, \mathbf{L a}$

$\mathrm{L}_{\mathrm{n}} \mathrm{CuGd} \quad \mathrm{J}=+5.68 \mathrm{~cm}^{-1}$

$\mathrm{Cu}$ - Gd J $=+5 \mathrm{~cm}^{-1}(\mathrm{R}=\mathrm{Me})$ $\mathrm{J}=+5.5 \mathrm{~cm}^{-1}(\mathrm{R}=\mathrm{Et})$ 
Metal carboxylate complexes [97], for instance $\mathbf{1 5 2}$ and 153, are mostly antiferromagnetic. Similar compounds with higher number of metal atoms are known, among which high-spin complexes (up to 51/2) have been isolated [98, 99].

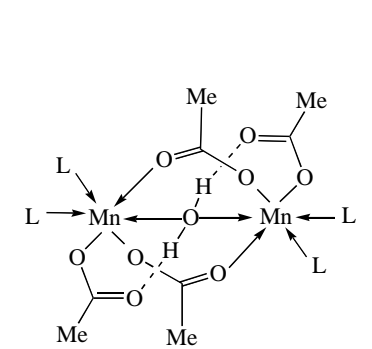

152

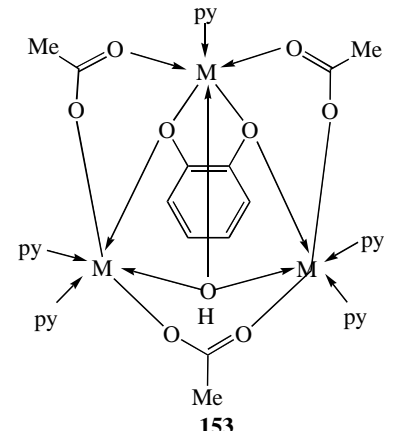

$\mathrm{M}=\mathrm{Mn}, \mathrm{Fe}, \mathrm{Co}, \mathrm{N}$
$\mathrm{L}=$ imidazole, benzimidazole, pyridine
A large series of interesting hydrazone antiferromagnetic complexes of types $\mathbf{1 5 4}$ and $\mathbf{1 5 5}$ have been reported [100, 101]. Depending on structure of ligand systems, in particular nature of $\mathrm{X}$, it is possible to regulate quantitatively the magnetic exchange parameters $-\mathrm{J}$.

Varying ligands, the intermetallic bridge, ferro-, antiferro-, and diamagnertic complexes have been synthesized [102-105]. Thus, for structurally characterized binuclear $\beta$-aminovinylimine complex with chloride bridge 156, a ferromagnetic interaction is typical (increasing temperature, the effective magnetic moment increases) [102,105].

Azomethine complex with sulfur bridge 157 is diamagnetic, meanwhile the chelate with an oxygen bridge 158 possesses a ferromagnetic moment [105].

A nitrogen bridge leads to compounds with ferromagnetic exchange, for instance 159 [103-105]. Complex of type 160 with sulfur bridge is unexpectedly ferromagnetic [105].

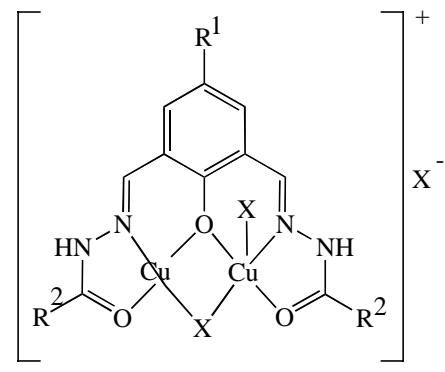

154

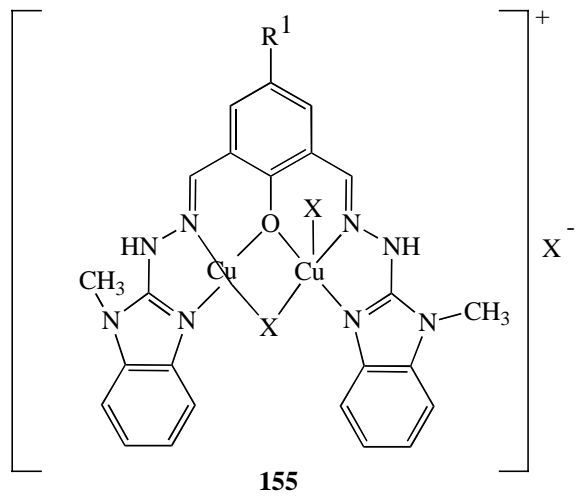

155<smiles>[R]C1=CN([R])C(Cl)(Cl)N([R])C1(Cl)Cl</smiles>

$\mathbf{R}^{1}, \mathbf{R}^{2}=$ Alk, ArAlk, OMe, COOMe, Cl, Br; X = Cl, Br.

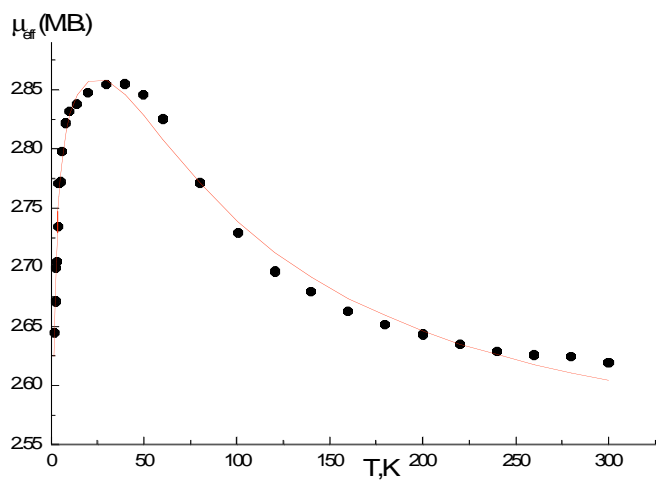

$\mathrm{g}=2.19, \mathrm{~J}=142 \mathrm{~K}\left(99 \mathrm{~cm}^{-1}\right), \mathrm{J}^{\prime} \mathrm{z}=-0.11 \mathrm{~K}\left(0.08 \mathrm{~cm}^{-1}\right)$,

Continuous line corresponds to theoretical calculations.

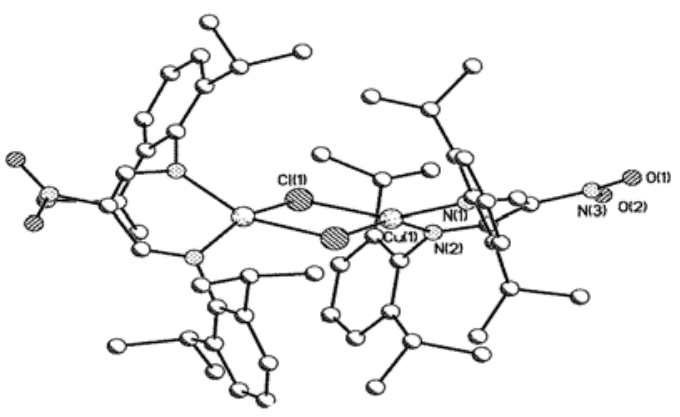

Structure of $\mathbf{1 5 6}$ 

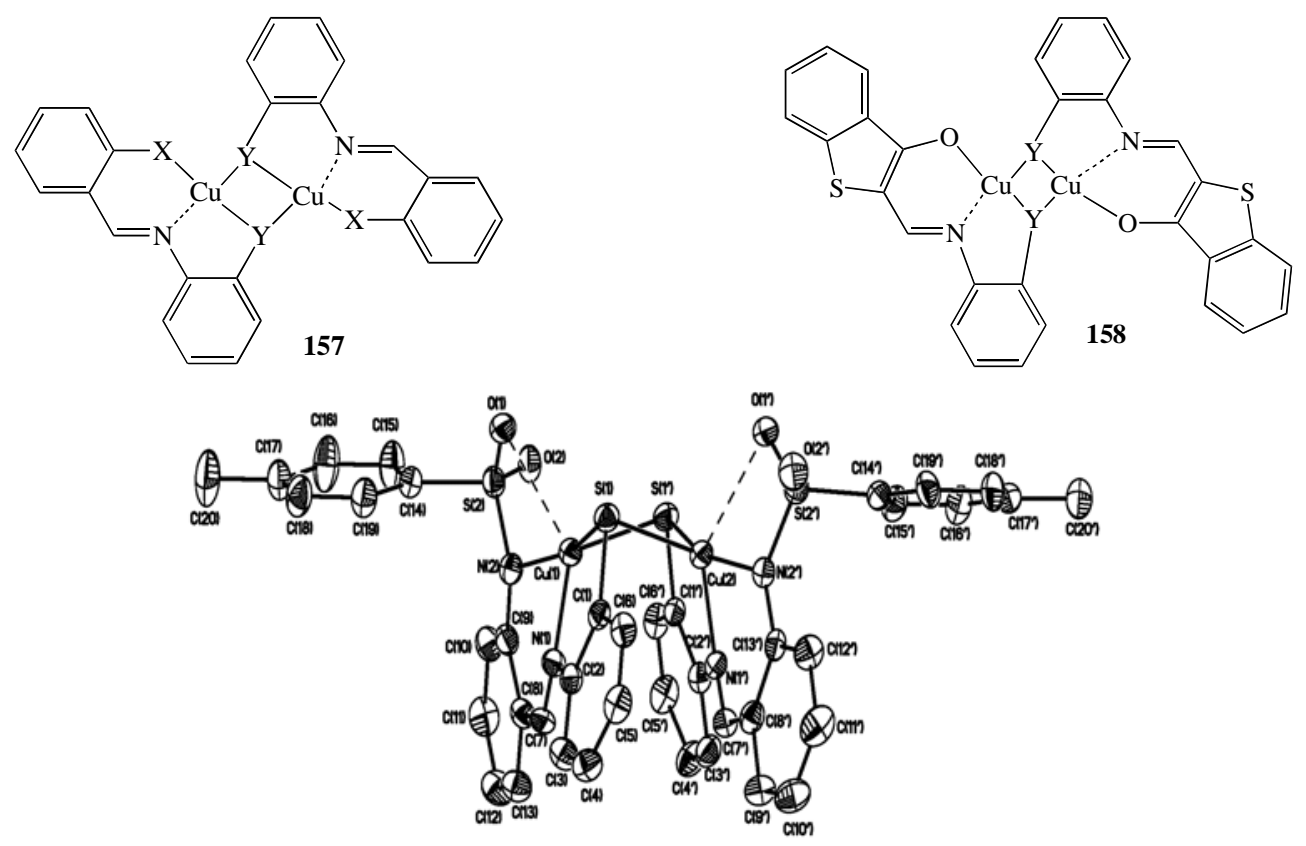

Structure of 157: $\mathrm{Y}=\mathrm{S}$, diamagnetic $; \mathrm{Y}=\mathrm{O}$, antiferromagnetic
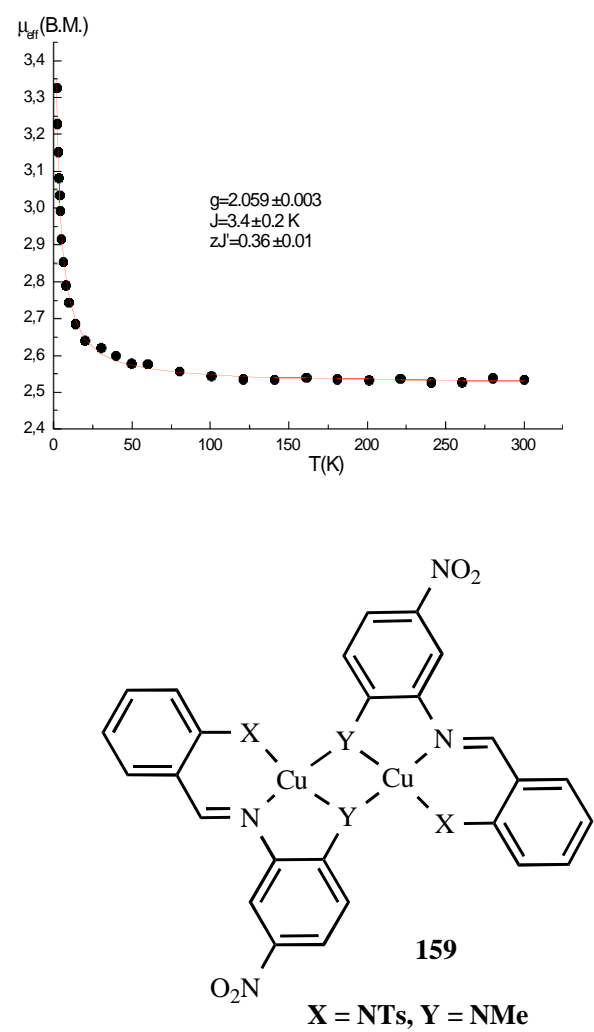

The same situation is observed for the complexes of type 161, 162 with antiferro- 161 or ferro- 162 magnetic interactions. In this case, it is quite probable (X-Ray data are required) existence of inner-chelate isomers with distinct ( $\mathrm{X}$ or Y) intermetallic bridges.

Complex compounds of azomethine 163-166, azine 167168, and azole 169-170 series are important among other functional materials $[41,91,92]$. They are luminescent in a
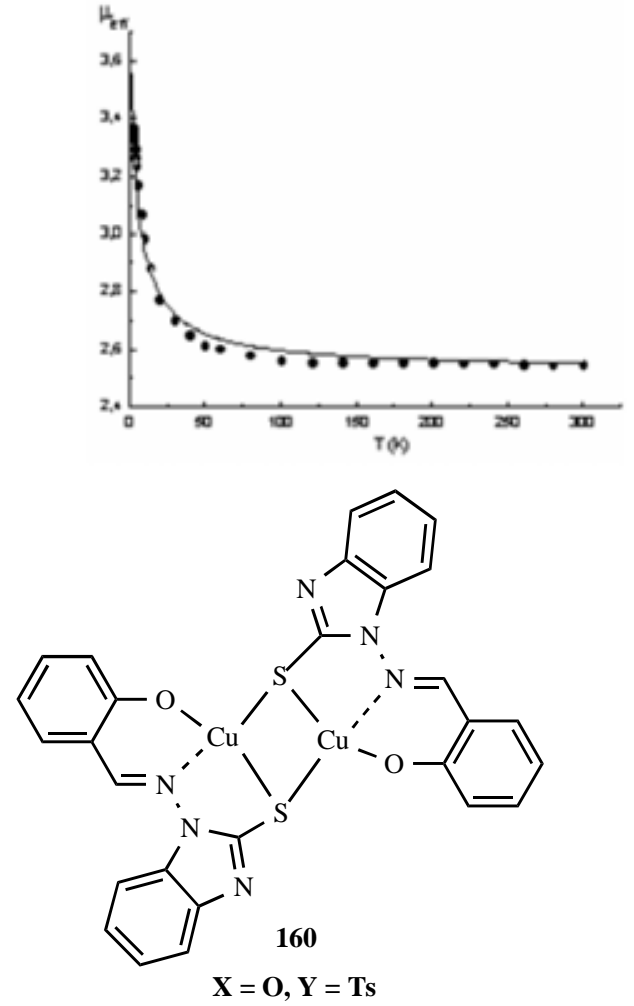

broad spectral range from visible (red, orange, blue, and violet) to IR-region $[41,91]$. Thus, complex compounds with blue fluorescence are discovered among mononuclear complexes [91]. In particular, mononuclear complexes of azomethine ligands 165, 166 and the polyheteronuclear complex compound 171 absorb in red and yellow spectral ranges. Luminescence of heteronuclear lanthanide complexes of type 172 was observed in IR region [91]. 

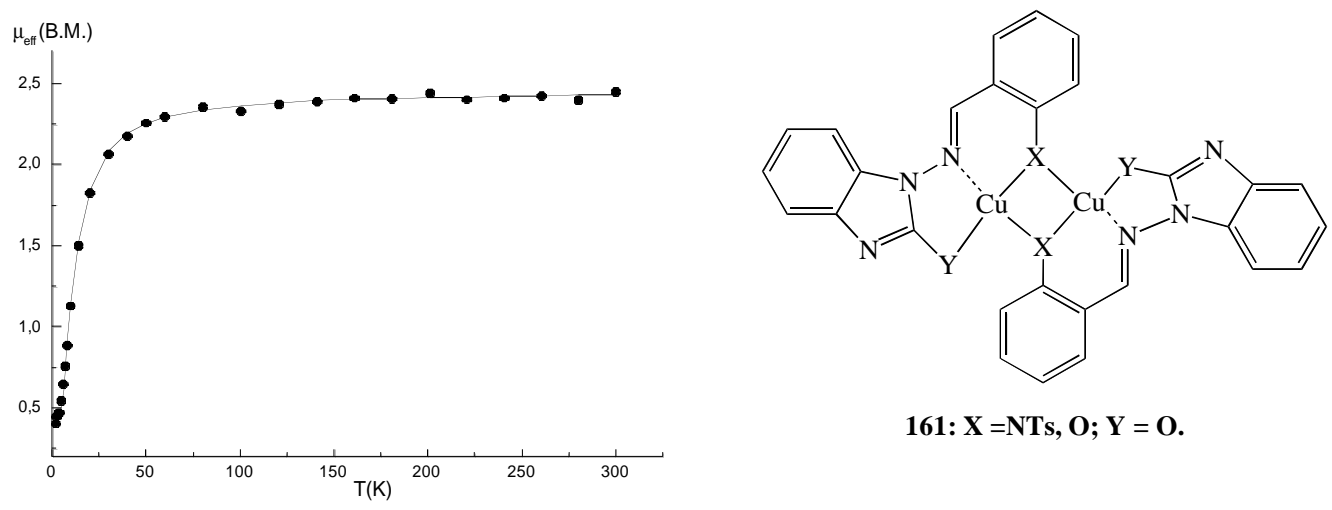

161: $X=N T s, O ; Y=O$.
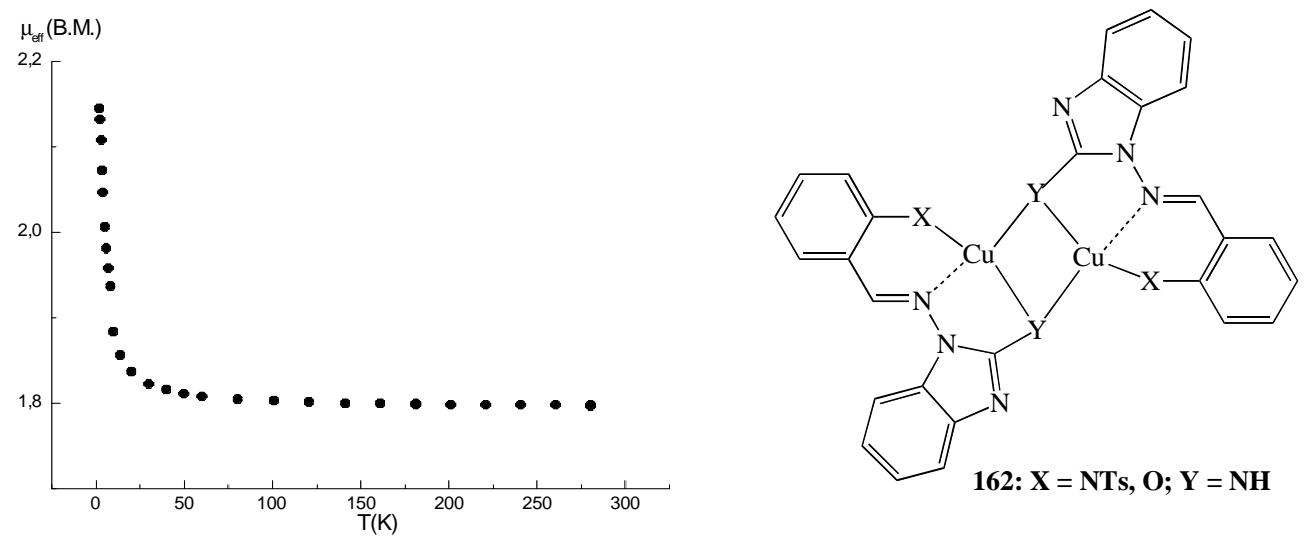<smiles>[X]c1ccccc1C=[N+]([R])[Y14]</smiles>

163<smiles>[X][X]c1ccccc1/N=C/c1ccccc1[X]</smiles>

164

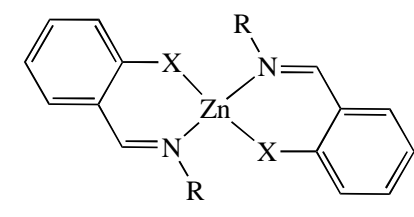

165

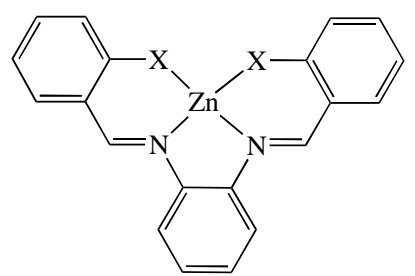

166

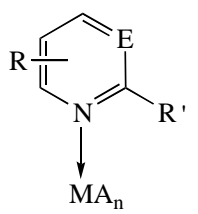

167<smiles>[X]c1ccc([R])c2c1ccc[n+]2[Y14]</smiles>

168

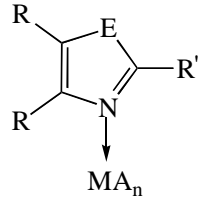

169

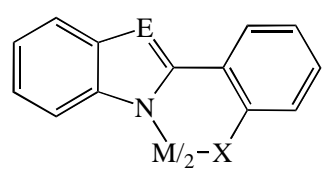

170

$\mathrm{X}=\mathrm{NTs}, \mathrm{O} ; \mathrm{E}=\mathrm{CH}, \mathrm{N}, \mathrm{NR}, \mathrm{O}, \mathrm{S} ; \mathrm{R}=\mathrm{H}, \mathrm{Alk}, \mathrm{Ar}$ 


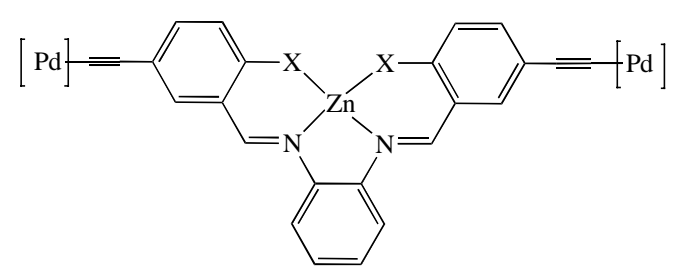

171

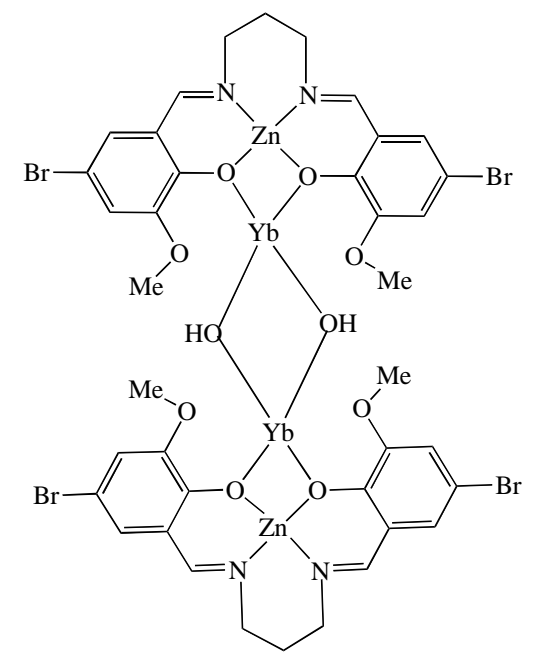

172
Among other applications of coordination compounds, we would like to mention their use in creation of new metalocomplex additives to lubricants, providing the effect of wear less friction [106-108]. In particular, easily accessible complexes of $o$-azomethines and hydrazones with copper and molybdenum are effective as additive.

\section{Perspectives of Coordination Chemistry}

The main direction of metal-complex chemistry in XXI century is emphasized in the title of [13]: "from biology to nanotechnology". $\beta$-Diketones and their analogues 173, diketonate complexes 174 [109], azomethinic 175 and heterocyc-

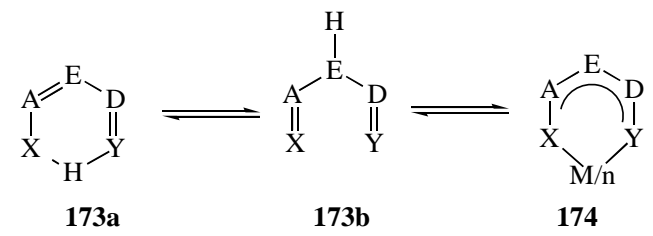

\section{A, D, E = CR, N, P, O; X, Y = NR', O, S, Se; R, R' = H, Alk, Ar, Het}<smiles>[R]B1N=C2C=CC=CC2[Y]1[H]</smiles>

175<smiles></smiles>

176

$A, B=C^{\prime}, N ; E=N R ', O, S$, Se, Te; X = NR', O, S; R, R', R'” = H, Alk, Ar, Het<smiles></smiles>

178<smiles></smiles>

177<smiles></smiles>

179<smiles>[Y]O[N+](=O)[O-]</smiles>

$\mathrm{M}=\mathrm{Ni}, \mathrm{Hg}, \mathrm{Pd}$ 


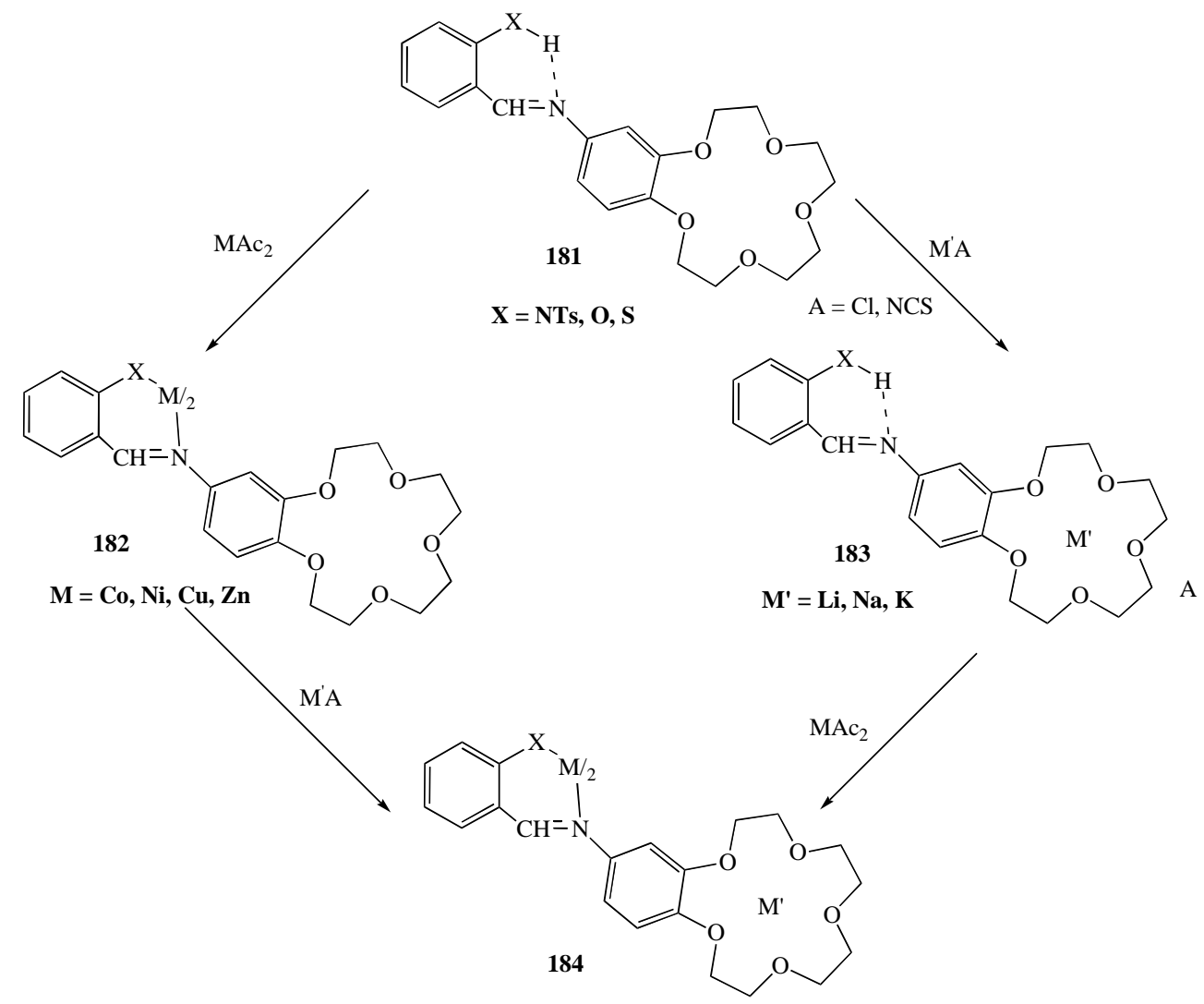

lic 176 ligans remain "eternal". Thus, the analysis of Cambridge Bank Database shows that about 2500 structures of complexes of the ligands of types $\mathbf{1 7 5}$ and $\mathbf{1 7 6}$ were resolved for 2000-2008.

Creation of new hard-soft ligand systems is also attractive. One of them 177 was just synthesized [41, 110-112] and then a series of transformations was carried out allowing obtaining complexes with hard-hard 178, hard-soft 179 and soft 180 coordination.

Creation of hybrid biologically perspective ligating systems, for example 181 [113-117], is also interesting. A cycle of transformations 181-184 was carried out, including such ligand 181 and its mononuclear azomethinic 182 and crownether 183 complexes, as well as binuclear structure 184 (confirmed by X-Ray diffraction). The principal goal is to work not only for theoretical, but also for practically useful coordination chemistry (competitive coordination), taking into account an operated creation of polyfunctional materials (for instance, selective electrodes). Other crown-containing azomethines are of a considerable interest as optically active chemosensors [118-121].

Modern achievements in coordination chemistry are presented in the Proceedings of the $38^{\text {th }}$ International Conference on Coordination Chemistry (ICCC38, Jerusalem, Israel, July 2008) [122].

\section{Nobel Prizes on Coordination Chemistry [123, 124]}

1912 Victor Grignard, Grignard's reagents.

1913 Alfred Werner, the area on the nature of bonds of atoms in molecules in inorganic chemistry.
1915 Rihard Vilshtetter, the area of pigments in plant world, especially chlorophill.

1930 Hans Fisher, investigation of construction of hemine and chlorophill.

1963 Karl Ziegler и Giulio Natta, discovery of isotactic polypropilene.

1964 Doroti Meri Kroufut Hodžkin, determination of structures of biologically active substances by X-Rays.

1973 Ernst Otto Fischer and Geoffrey Wilkinson, organometallic chemistry.

1987 Donald James Cram, Jean-Marie Lehn and Charles J. Pedersen, elaboration and applications of molecules having structurally-specified interactions of high selectivity.

2001 William S. Knowles, Ryoji Noyori and K. Barry Sharpless, research in pharmaceutical industry: creation of chiral catalysts for redox-reactions.

2005 Yves Chauvin, Robert H. Grubbs, Richard R. Schrock, the development of the metathesis method in organic synthesis.

\section{ACKNOWLEDGEMENTS}

The authors are grateful to numerous researchers of the Institute of Physical and Organic Chemistry (Southern Federal University, Rostov-na-Donu, Russia) for their help, the Russian President grant HШ-363.2008.3, and to PaicytUANL (Monterrey, Mexico, project 2008) for the financial support. 


\section{REFERENCES}

[1] Shriver, D.F.; Atkins, P.W. Inorganic Chemistry, University Press: Oxford, 1999.

[2] Tretyakov, Yu.D.; Martynenko, Yu.D.; Grigoriev, A.N.; Tsivadze, A.Yu. Inorganic Chemistry, Khimiya: Moscow, 2001.

[3] Day, M.C.; Selbin, D. Theoretical Inorganic Chemistry, Reinhold Book Corporation: New-York-Amsterdam-London, 1973.

[4] Cotton, F.A.; Wilkinson, G. Basic Inorganic Chemistry, Wiley: New-York, 1976.

[5] Cotton, F.A.; Wilkinson, G.; Murillo, C.A.; Bochman, M. Advanced Inorganic Chemistry, $6^{\text {th }}$ ed.; Wiley: New York, 1999.

[6] Grinberg, A.A. Introduction in Chemistry of Complex Compounds; Khimiya: Leningrad, 1971.

[7] Kukushkin, Yu.N. Chemistry of Coordination Compounds; Vysshaya Shkola: Moscow, 1985.

[8] Kostromina, N.A.; Kumok, V.N.; Skorik, N.A. Coordination Chemistry. Moscow: Vysshaya Shkola, 1990.

[9] Minkin, V.I.; Simkin, B.Ya.; Minyaev, R.M. Theory of Molecule Structure (Chapter 11). Fénix: Rostov-na-Donu, 1997.

[10] Skopenko, V.V.; Tsivadze, A.Yu.; Savranskii, L.I.; Garnovskii, A.D. Coordination Chemistry. Akademkniga: Moscow, 2007.

[11] Gade, L.H.. Koordinationschemie, VCH: Weinheim-New YorkToronto, 1998.

[12] In Comprehensive Coordination Chemistry I, Wilkinson, G.; Gillard, R.D.; Mc Cleverty, J.A. Eds.; Elsevier: Oxford-New-York, 1987, V. 1-7.

[13] In Comprehensive Coordination Chemistry II, McCleverty, J.A.; Meyer, T.J. Ed. Elsevier-Pergamon Press; Oxford-New York, 2003, V. 1-10

[14] In Synthetic Coordination and Organometallic Chemistry, Garnovskii, A.D.; Kharisov, B.I. Eds.; Marcel-Dekker: New YorkBasel, 2003.

[15] Metal chelates. Ross. Khim. J. 1996, 40(4-5), 3 (all issue); Mendeleev Chem. J. (Zhurn. Ross. Khim. Ob-va im. D.I. Mendeleeva. 1996, 40(4-5), part I-II.

[16] Progress in Coordination Chemistry. Ross. Khim. J., 2004, 48(1), 3 (all issue).

[17] Garnovskii, A.D.; Sennikova, E.V.; Kharisov, B.I. Chem. Educator, 2008, 13, 67.

[18] The Chemistry of Coordination Compounds, Bailar, J.; Busch, D.H. Ed.; Capman-Hall: New York-London, 1956.

[19] Lehn, J.-M. Supramolecular Chemistry Consept in Perspectives, VCH: Weinheim-New York-Basel-Cambridge-Tokio, 1995.

[20] Steed, J.W.; Atwood, J.L. Supramolecular Chem., Willey: Chichester, 2002.

[21] Encyclopedia of Supramolecular Chemistry, Atwood, J.L.; Steed, J.W. Marsel Dekker: New-York, 2004.

[22] Garnovskii, A.D.; Sadimenko, A.P. Adv. Heterocycl. Chem., 1998, 72,1 .

[23] Omae, I. Organometallic Intramolecular-Coordination Compounds, Elsevier: Amsterdam-New York, 1986.

[24] Cotton, F.A.; Walton, R.A. Multiple Metal-Metal Bonds, Wiley: New York-Chichester, 1982.

[25] Kostromina, N.A.; Voloshin, Ya.Z.; Nazarenko, A.Yu. Clatrochelates: Synthesis, Structure, Properties, Naukova Dumka: Kiev, 1992.

[26] Voloshin, Ya.Z.; Kostromina, N.A.; Kramer, J. Chlatrochelates: Synthesis, Structure and Properties, Elsevier: Amsterdam, 2002.

[27] Kukushkin, V.Yu.; Kukushkin, Yu.N. Theory and Practice of Synthesis of Coordination Compounds, Nauka: Leningrad, 1990.

[28] Davies, J.A.; Hokensmith, C.M.; Kukusnkin, V.Yu.; Kukusnkin, Yu.N. 1996. Synthetic Coordination Chemistry. Principle and Practice, World Scientific: Singapore, 1998.

[29] Handbuch der Preparativen Anorganichen Cheime, Herausgeben von G. Brauer., Bd. 3. Ferdinand-Enke Verlag: Stutgart, 1981.

[30] Hoss, R.; Fogtle, F. Templatsynthesen. Angew. Chem., 1994, 106(4), 389.
[31] Yatsimirskii, K.B.; Kolchinskii, A.G.; Pavlischuk, V.V.; Salanova, G.G. Synthesis of Macrocyclic Compounds, Naukova Dumka: Kiev, 1987.

[32] Gerbeleu, N.V.; Arion, V.B. Template Synthesis of Macrocyclic Compounds, Shtiintsa: Kishinev, 1990.

[33] Gerbeleu, N.V.; Arion, V.B.; Bargess, J. Synthesis of Macrocyclic Compounds, Wiley-VCH: Weinheim, 1999.

[34] Garnovskii, A.D.; Vasilchenko, I.S. Usp. Khim., 2002, 71(11), 1064: Russ. Chem. Rev. 2002, 71(11), 943.

[35] Garnovskii, A.D. Russ. J. Coord. Chem., 1993, 19(5), 368.

[36] (a). Vigato, P.A.; Tamburini, S. Coord. Chem. Rev., 2004, 248, 1717. (b). Vigato, P.A.; Tamburini, S.; Bertolo L. Coord. Chem. Rev., 2007, 251, 1311. (c). Vigato, P.A.; Tamburini, S. Coord. Chem. Rev., 2008, 252, 1871.

[37] Burlov, A.S.; Koshchienko, Yu.V.; Lyssenko K.A.; Vasilchenko, I.S.; Alexeev, Yu.E.; Borodkina, I.G.; Antipin M.Yu.; Garnovskii, A.D. J. Coord. Chem., 2008, 61(1), 85.

[38] Hiraoka, M. Crown Compounds, Elsevier: New York, 1982

[39] Lenznoff, C.C.; Lever, A.B.P. Eds.; In Phthalocyanines. Properties and Application, Verlag Chemie: New York, 1990-1996, V. 1-4.

[40] Burlov, A.S.; Lyssenko K.A.; Koshchienko, Yu.V.; Vasilchenko, I.S.; Garnovskii, D.A.; Uraev, A.I.; Garnovskii, A.D. Mendeleev Commun., 2008, 18(4), 198.

[41] Garnovskii, A.D.; Sennikova, E.V. Chem. Heterocyl. Comp., 2007, 43(11), 1359.

[42] In Direct Synthesis of Coordination and Organometallic Compounds, Garnovskii, A.D.; Kharisov, B.I. Eds.; Elsevier: Amsterdam, 1999.

[43] Cassoux, P.; Valade, L. In: Comprehensive Coordination Chemistry, McCleverty, J.A.; Meyer, T.J. Eds.; Elsevier-Pergamon Press: Oxford-New York, 2003, 1, p. 761.

[44] Tuck, D.G. In: Molecular Electrochemistry of Inorganic, Bioinorganic, and Organometallic Compounds. Kluwer Acad. Publishers Dortrecht, 1993, 15.

[45] Kharisov, B.I.; Garnovskii, A.D.; Tsivadze, A.Yu.; Kharissova O.V.; Mendez, U.O. J. Coord. Chem., 2007, 60(12-14), 1435.

[46] Garnovskii, D.A.; Burlov, A.S.; Garnovskii, A.D.; Vasilchenko, I.S. Zhurn. Obsch. Khim., 1996, 66(9), 1546.

[47] Kukushkin, Yu.N. Reactive Capacity of Coordination Compounds. Khimiya: Leningrad, 1987.

[48] Constable, E.C. Metals and Ligand Reactivity. VCH: Weinheim, 1995.

[49] Pombeiro, A.J.L.; Kukushkin, V.Yu. In: Comprehensive Coordination Chemistry II, McCleverty, J.A.; Meyer, T.J. Eds.; ElsevierPergamon Press: Oxford-New York, 2003, 1, 585.

[50] Kukushkin, V.Yu.; Pombeiro, A.J.L. Chem. Rev., 2002, 102, 1771.

[51] Garnovskii, D.A.; Silva, M.F.C.G., Pachomova, T.B.; Wagner, G.; Silva, J.J.R.F. Inorg. Chim. Acta, 2000, 300, 499.

[52] Garnovskii, D.A.; Kukushkin, V.Yu.; Haukka, M.; Wagner, G.; Pombeiro, A.J.L. Dalton Trans., 2001, 5, 560.

[53] Bokach, N.A.; Kukushkin, V.Yu.; Kuznetsov, M.L.; Garnovskii, D.A.; Natile, G.; Pombeiro, A.J.L. Inorg. Chem., 2002, 41(8), 2041.

[54] Makarycheva-Mikhaylova, A.V.; Kukushkin, V.Yu.; Nazarov, A.A.; Garnovskii, D.A.; Pombeiro, A.J.L.; Haukka, M.; Keppler, B.K.; Galansky, M. Inorg. Chem., 2003, 42(8), 2805.

[55] Luzyanin, K.V.; Kukushkin, V.Yu.; Kuznetsov, M.L.; Garnovskii, D.A.; Haukka, M.; Pombeiro, A.J.L. Inorg. Chem., 2002, 41(11), 2981.

[56] Makarycheva-Mikhaylova, A.V.; Haukka, M.; Bokach, N.A.; Garnovskii, D.A.; Galanski, M.; Keppler, B.K.; Pombeiro, A.J.L.; Kukushkin, V.Yu. New J. Chem., 2002, 26(8), 1085.

[57] Makarycheva-Mikhaylova, A.V.; Nazarov, A.A.; Haukka, M.; Garnovskii, D.A.; Keppler, B.K.; Galansky, M.; Pombeiro, A.J.L.; Kukushkin, V.Yu. Inorg. Chem., 2003, 42(8), 2805.

[58] Garnovskii, D.A.; Pombeiro, A.J.L.; Haukka, M.; Sobota, P.; Kukushkin, V.Yu. Dalton Trans., 2004, 7, 1097. 
[59] Garnovskii, D.A.; Kukushkin, V.Yu. Vestnik RFFI, 2005, 43(5), 13.

[60] Garnovskii, D.A.; Bokach, N.A.; Pombeiro, A.J.L.; Haukka, M.; da Silva, J.J.R., Kukushkin, V.Yu. Eur. J. Inorg. Chem., 2005, 11, 3467.

[61] Garnovskii, D.A.; Kukushkin, V.Yu. Usp. Khim., 2006, 75(2), 125; (Russ. Chem. Rev., 2006, 75(2), 125).

[62] Garnovskii, D.A.; Garnovskaya, E.D.;Uraev, E.D.; Uraev, A.I.; Xaukka, M.; Eremenko, I.L.; Kukushkin, V.Yu. Izv. Akad. Nauk, Ser. Khim., 2006, 55(9), 1572; (Russ. Chem. Bull., 2006, 55(9), 1631).

[63] Nivorozhkin, A.L.; Uraev, A.I.; Burlov, A.S.; Garnovskii, A.D. Mendeleev Chem. J. (Zhurn. Ross. Khim. Ob-va im. D.I. Mendeleeva), 1996, 40(4-5), 255.

[64] Madal, S.; Das, G.; Singh, R. Coord. Chem. Rev., 1997, 160, 191.

[65] Bioinorganic Chemistry. Mendeleev Ross. Khim. J. 2004, 4, 3 (all issue).

[66] Holm, R.H.; Solomon, E.I. Eds. Biomimetic Inorganic Chemistry, Chem. Rev., 2004, 104(2), 347.

[67] Uraev, A.I.; Nivorozhkin, A.L.; Bondarenko, G.I.; Lyssenko, K.A.; Korshunov, O.Yu.; Vlasenko, V.G.; Shuvaeva, A.T.; Kurbatov, V.P.; Antipin, M.Yu.; Garnovskii, A.D. Izv. Akad. Nauk, Ser. Khim., 2000, 11, 1891.

[68] Kitajima, N.; Fujisawa, K.; Tanaka, M.; Moro-oka, Y. J. Am. Chem. Soc., 1992, 114, 9232.

[69] Chasteen, N.D. Ed.; Vanadium in Biological Systems, Kluwer: Dordrecht, 1990.

[70] Zhdanov, Yu.A.; Alexeev, Yu.E. Usp. Khim., 2002, 71(11), 1090.

[71] Alexeev, Yu. E.; Vasilchenko, I.S.; Kharisov, B.I.; Blanko, L.M.; Garnovskii, A.D.; Zhdanov, Yu.A. J. Coord. Chem., 2004, 57(1718), 1447.

[72] Garnovskii, A.D.; Osipov, O.A.; Bulgarevich, S.B. Russ. Chem. Rev., 1972, 41, 341

[73] Pearson, R.G. J. Am. Chem. Soc., 1963, 85, 3533

[74] Burmeister, J.L. Coord. Chem. Rev., 1990, 105, 77.

[75] Garnovskii, A.D.; Garnovskii, D.A.; Vasilchenko, A.P.; Burlov, A.S.; Sadimenko, A.P.; Sadekov, I.D. Russ. Chem. Rev., 1997, $66(5), 389$.

[76] Garnovskii, A.D.; Sadimenko, A.P.; Sadimenko, M.I.; Garnovskii, D.A. Coord. Chem. Rev., 1998, 173, 31

[77] The Chemistry of Pseudohalides, Golub, A.M.; Keler, H.; Skopenko, V.V. Ed.; Elsevier Science: Lausanne-Amsterdam-New York -Tokyo, 1986.

[78] Covert, K.J.; Neithamer, D.R.; Zonnevylle, M.C.; LaPointe, R.E.; Schaller, C.P.; Wolczanski, P.T. Inorg. Chem., 1991, 30, 2494.

[79] Sadimenko, A.P. Adv. Heterocycl. Chem., 2001, 81, 167.

[80] Garnovskii, A.D.; Osipov, O.A.; Kuznetsova, L.I.; Bogdashev, N.N. Usp. Khim., 1973, 42(2), 177; (Russ. Chem. Rev., 1973, 43(2), 89).

[81] Perera, J.R.; Heeg, M.J.; Schlegel, H.D.; Winter, C.H. J. Am. Chem. Soc., 1999, 121, 4536.

[82] Wang, D.; Wurst, K.; Buchmeiser, M.R. J. Organomet. Chem., 2004, 689, 2123.

[83] Kawaguchi, S. Variety in Coordination Modes of Ligands in Metal Complexes. Springer Verlag Chemie: Berlin, 1988.

[84] Garnovskii, A.D.; Vasilchenko, I.S. Russ. Chem. Rev., 2005, 74(3), 193.

[85] Sergienko, V.S.; Mistryukov, A.E.; Litvinov, V.V.; Knyazhanskii, M.I.; Garnovskii, A.D.; Porai-Koshits, M.A. Koord. Khim., 1990, 16(2), 168.

[86] Torzilli, M.A.; Colquhoun, S.; Doucet, D.; Beer, R.H. Polyhedron, 2002, 21, 697.

[87] Kogan, V.A.; Antsyshkina, A.S.; Sadikov, G.G.; Sergienko, V.S.; Scherbakov, I.N.; Kochin, S.G.; Garnovskii, A.D. Zhurn. Neorg. Khim., 2004, 49(12), 1988.

[88] Kogan, V.A.; Scherbakov, I.N. Ross. Khim. J. (Zhurn. Ros. Khim. ob-va im D.I.Mendeleeva), 2004, 48(1), 69.
[89] Garnovskii, A.D.; Uraev, A.I.; Minkin, V.I. Arkivoc (iii), 2004, 3, 29.

[90] Tompson, K.L. Magnetism: Molecular and Supramolecular Perspective, Ed.; Coord. Chem. Rev., 2005, 249, 2549.

[91] Metelitsa, A.V.; Burlov, A.S.; Bezuglyi, S.O.; Borodkina, I.G.; Bren, V.A.; Garnovskii, A.D.; Minkin, V.I. Russ. J. Coord. Chem., 2006, 32(12), 858.

[92] Kuzmina, N.P.; Eliseeva, S.V. Zhurnal. Neorg. Khim., 2006, 51(1), 80.

[93] Organic Light-Emmiting Devices, Mueller, K.; Schert, U. Eds.; Wiley-VCH: Weinheim-New York, 2006.

[94] Single-Molecule Magnets and Related Phenomena, Winpenny. R. Ed.; Structure and Bonding. 2006, Vol. 122

[95] Ovcharenko, V.I.; Sagdeev, R.Z. Russ. Chem. Rev., 1999, 68(5), 345.

[96] Sato, O. Acc. Chem. Res., 2003, 36, 692.

[97] Kiskin, M.A.; Eremenko, I.A. Russ. Chem. Rev., 2006, 75(7), 559.

[98] Foguet-Albiol, D.; O’Brien, T.A.; Wernsdorfer, W.; Moulton, B.; Zaworotko, M.J.; Abboud, K.A.; Christou, G. Angew. Chem. Int. Ed. Engl., 2005, 44, 897.

[99] Murugesu, M.; Habrych, M.; Wernsdorfer, W.; Abboud, K.A.; Christou, G. J. Am. Chem. Soc., 2004, 126, 4766.

[100] Kogan, V.A.; Lukov, V.V. Koord. Khim., 1997, 23(1), 18.

[101] Lukov, V.V.; Levchenko, S.I.; Scherbakov, I.N.; Kogan, V.A. Koord. Khim., 1997, 23(7), 544.

[102] Uraev, A.I.; Ikorskii, V.N.; Lyssenko, K.A.; Vlasenko, K.A.; Borodkina, I.G.; Borodkin, G.S.; Garnovskii, D.A.; Garnovskii, A.D. Koord. Chem., 2006, 32(4), 299.

[103] Burlov, A.S.; Koschienko, Yu.V.; Ikorskii, V.N.; Vlasenko, V.G.; Zarubin, I.A.; Uraev, A.I.; Vasilchenko, I.S.; Garnovskii, D.A.; Borodkin, G.S.; Nikolaevskii, S.A.; Garnovskii, A.D. Zhurn. Neorg. Khim., 2006, 51(7), 1143.

[104] Burlov, A.S.; Ikorskii, V.N.; Uraev, A.I.; Koschienko, Yu.V.; Vasilchenko, I.S.; Garnovskii, D.A.; Borodkin, G.S.; Nikolaevskii, S.A.; Garnovskii, A.D. Zhurn. Obsch. Khim., 2006, 76(8), 1337.

[105] Garnovskii, A.D.; Ikorskii, V.N.; Uraev, A.I.; Vasilchenko, I.S.; Burlov, A.S.; Garnovskii, D.A.; Lyssenko, K.A.; Vlasenko, V.G.; Shestakova, T.E.; Koshchiehko, Yu.V.; Kuz'menko, T.A.; Divaeva, L.N.; Bubnov, M.P.; Rybalkin, V.P.; Korshunov, O.Yu.; Pirog, I.V.; Borodkin, G.S.; Bren, V.A.; Uflyand, I.E.; Antipin, M.Yu.; Minkin, V.I. J. Coord. Chem., 2007, 60(12-14), 1493

[106] Chigarenko, G.G.; Ponomarenko, A.G.; Bolotnikov, V.S.; Alexeev, V.A.; Burlov, A.S.; Garnovskii, A.D.; Barchan, G.P. Koord. Khim., 1989, 10(6), 1051

[107] Garkunov, D.N. Tribotechnique (Deterioration and nondeterioration)., MSHA Editoria: Moscow, 2001, p. 614.

[108] Burlov, A.S.; Uraev, A.I.; Lyssenko, K.A.; Chigarenko, G.G.; Ponomarenko, A.G.; Matuev, P.V.; Nikolaevskii, S.A.; Garnovskaya, E.D.; Borodkin, G.S.; Garnovski, A.D. Russ. J. Coord. Chem., 2006, 32(8), 686.

[109] Skopenko, V.V.; Amirkhanov, B.M.; Sliva T.Yu.; Vasilchenko, I.S.; Anpilova, E.L.; Garnovskii, A.D. Usp. Khim., 2004, 73(8), 797; (Russ. Chem. Rev., 2004, 74, 737).

[110] Sennikova, E.V.; Borodkina, I.G.; Antsyshkina, A.S. Sadikov, G.G.; Bicherov, A.V.; Korshunov, O.Yu.; Borodkin, G.S.; Korobov, M.S.; Sergienko, Kharabaev, N.N.; Garnovskii, A.D. Russ. J. Inorg. Chem., 2006, 51(10), 1548.

[111] Sennikova, E.V.; Korshunov, O.Yu.; Borodkin, G.S.; Korobov, M.S.; Vlasenko, V.G.; Kharabaev, N.N.; Garnovskii, A.D. Russ. J. Gener. Chem., 2007, 77(10), 1738.

[112] Sennikova, E.V.; Antsyshkina, A.S. Sadikov, G.G.; Bicherov, A.V.; Korshunov, O.Yu.; Borodkin, G.S.; Korobov, M.S.; Sergienko, V.S.; Kharabaev, N.N.; Garnovskii, A.D. Russ. J. Coord. Chem., 2008, 34(5), 315 .

[113] Minacheva, L.H.; Ivanova, I.S.; Dorokhov, A.V.; Bicherov, A.V.; Burlov, A.S.; Garnovskii, A.D.; Sergienko, V.S.; Tsivadze A.Yu. Dokl. Akad. Nauk., Ser. Khim., 2004, 398(1), 62. 
[114] Ivanova, I.S.; Dorokhov, A.V.; Pyatova, E.N.; Bicherov, A.V.; Burlov, A.S.; Garnovskii, A.D.; Sergienko, V.S.; Tsivadze, A.Yu. Koord. Khim., 2005, 31(7), 512.

[115] Minacheva, L.H.; Ivanova, I.S.; Dorokhov, A.V.; Burlov, A.S.; Garnovskii, A.D.; Sergienko, V.S.; Tsivadze, A.Yu. Koord. Khim., 2006, 32(3), 174.

[116] Burlov, A.S.; Tsukanov, A.V.; Borodkin, G.S.; Revinskii, Yu.V.; Dubonosov, A.D.; Bren, V.A.; Garnovskii, A.D.; Tsivadze, A.Yu.; Minkin, V.I. Zhurn. Obsch. Khim., 2006, 76(6), 1037.

[117] Dorohov, A.V.; Chernyshov, D.Yu.; Burlov, A.S.; Ganovskii, A.D.; Ivanova, I.S.; Pyatova, E.N.; Tsivadze, A.Yu.; Aslanov, L.A.; Chernyshev, V.V. Acta Crystallogr. B, 2007, B. 63, 402.

[118] Dubonosov, A.D.; Minkin, V.I.; Popova, L.L.; Shepelenko, E.N.; Tkalina, N.N.; Tsukanov, A.V. Bren, V.A. Arcivoc, 2003, 13, 12.
[119] Bren, V.A.; Dubonosov, A.D.; Popova, L.L.; Rybalkin, V.P.; Sadekov, I.D.; Shepelenko, E.N.; Tsukanov, A.V. Arcivoc, 2005, 7, 60.

[120] Bren, V.A.; Dubonosov, A.D.; Minkin V.I.; Gribanova, N.N.; Rybalkin, V.P.; Shepelenko, E.N.; Tsukanov, A.V.; Borisenko, R.N. Mol. Cryst. Liq. Cryst., 2005, 431, 417.

[121] Bren, V.A.; Dubonosov, A.D.; Minkin V.I.; Tsukanov, A.V.; Gribanova, N.N.; Shepelenko, E.N.; Revinsky, Y.V.; Rybalkin, V.P. J. Phys. Org. Chem., 2007, 20(11), 917.

[122] $38^{\text {th }}$ International Conference on Coordination Chemistry (ICCC38). Jerusalem, Israel, July 20-25, 2008. http://www.kenes.com/iccc38. Accessed August 6, 2008.

[123] Volkov, V.A.; Vonskii, E.V.; Kuznetsova, G.I. Outstanding chemists worldwide. Vysshaya Shkola: Moscow, 1991.

[124] http://nobelprize.org/nobel_prizes/chemistry/laureates/index.html.

Received: July 25, 2008

(c) Garnovskii et al.; Licensee Bentham Open.

This is an open access article licensed under the terms of the Creative Commons Attribution Non-Commercial License (http://creativecommons.org/licenses/by-nc/3.0/) which permits unrestricted, non-commercial use, distribution and reproduction in any medium, provided the work is properly cited. 